GA-A15956

UC-77

\title{
PEBBLE BED REACTOR \\ FISCAL YEAR 1980 REVIEW SUMMARY REPORT
}

\author{
by \\ PROJECT STAFF
}

\author{
Prepared under \\ Contract DE-AT03-76ET35300 \\ for the \\ San Francisco Operations Office \\ Department of Energy
}

DATE PUBLISHED: JULY 1980 


\section{DISCLAIMER}

This report was prepared as an account of work sponsored by an agency of the United States Government. Neither the United States Government nor any agency Thereof, nor any of their employees, makes any warranty, express or implied, or assumes any legal liability or responsibility for the accuracy, completeness, or usefulness of any information, apparatus, product, or process disclosed, or represents that its use would not infringe privately owned rights. Reference herein to any specific commercial product, process, or service by trade name, trademark, manufacturer, or otherwise does not necessarily constitute or imply its endorsement, recommendation, or favoring by the United States Government or any agency thereof. The views and opinions of authors expressed herein do not necessarily state or reflect those of the United States Government or any agency thereof. 


\section{DISCLAIMER}

Portions of this document may be illegible in electronic image products. Images are produced from the best available original document. 
This report was prepared as an account of work sponsored by an agency of the United States Government. Neither the United States Government nor any agency thereof, nor any of their employees, makes any warranty, express or implied, or assumes any legal liability or responsibility for the accuracy, completeness, or usefulness of any information, apparatus, product, or process disclosed, or represents that its use would not infringe privately owned rights. Reference herein to any specific commercial product, process, or service by trade name, trademark, manufacturer, or otherwise, does not necessarily constitute or imply its endorsement, recommendation, or favoring by the United States Government or any agency thereof. The views and opinions of authors expressed herein do not necessarily state or reflect those of the United States Government or any agency thereof.

Printed in the United States of America Available from

National Technical Information Service

U.S. Department of Commerce

5285 Port Royal Road

Springfield, VA 22161

NTIS Price Codes: Printed Copy A04; Microfiche A01 
GA-A15956 UC-77

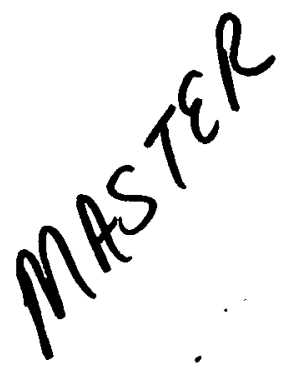

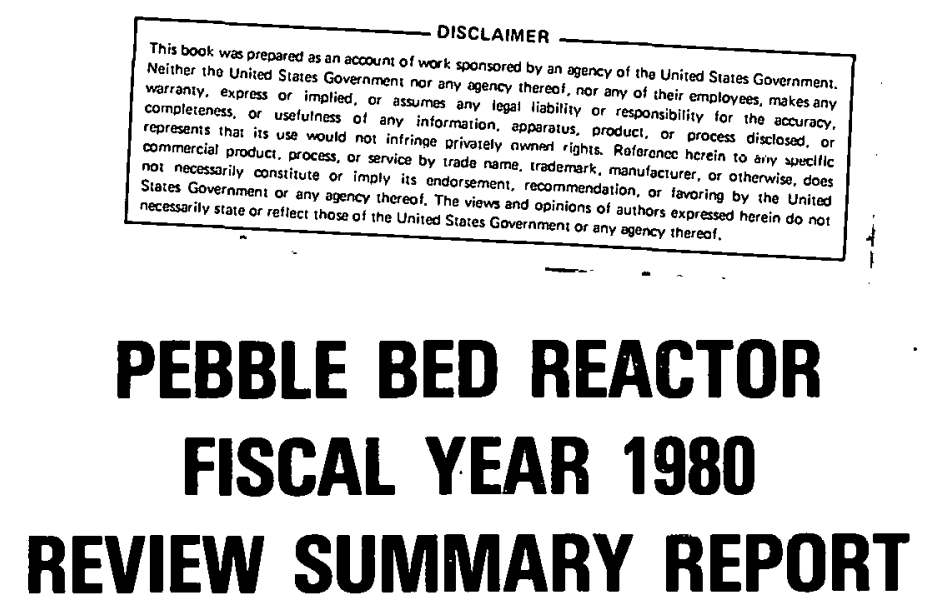

by

PROJECT STAFF

Prepared under

Contract DE-AT03-76ET35300

for the

San Francisco Operations Office

Department of Energy

GENERAL ATOMIC PROJECT 6400 DATE PUBLISHED: JULY 1980

DISTAIBUTIOH OF THIS DOCUMENT IS UNLIMITED

\section{GENERAL ATOMIC COMPANY}


THIS PAGE

\section{WAS INTENTIONALLY \\ LEFT BLANK}




\section{ABSTRACT}

This report provides results of performance evaluations and reviews of key technical features by General Atomic Company of the pebble bed reactor (PBR) concept under development in the Federal Republic of Germany (FRG) for electricity generation and process heat applications. Participation not reported herein includes work by General Electric Company (GE), Oak Ridge National Laboratory (ORNL), and Gas-Cooled Reactor Asssociates (GCRA). This report presents core performance analyses conclusions, safety comments, and maintenance and availability reviews developed during FY-80. Summary comments compare the $\mathrm{PBR}$ and prismatic fuel high-temperature gas-cooled reactor (HTGR) concepts. 
THIS PAGE

\section{WAS INTENTIONALLY \\ LEFT BLANK}




\section{CONTENTS}

ABSTRACT . . . . . . . . . . . . . . . . . . . . . . 111

1. INTRODUCTION . . . . . . . . . . . . . . . . 1-1

References ...................... . . . 1-2

2. SUMMARY AND CONCLUSIONS ................. . . . 2-1

Reference ......... . . . . . . . . . . . . 2-5

3. REACTOR OPERATING EXPERIENCE . . . . . . . . . . . . . 3-1

3.1 Prismatic . . . . . . . . . . . . . . . 3-1

3.2 Pebble Bed ..................... . . . 3-2

4. CORE PERFORMANCE ASSESSMENT ................ . . . 4-1

4.1 General . . . . . . . . . . . . . . . 4-1

4.2 Physics . . . . . . . . . . . . . . . . . 4-2

4.3 Thermal-Hydraulic . . . . . . . . . . . . 4-3

4.4 Fuel Performance and Fission Product Release . . . . . 4-6

References ...................... . . 4-9

5. CORE CONTROL AND SHUTDOWN .. . . . . . . . . . . . . 5-1

References ...................... 5-3

6. REFLECTOR AND CORE SUPPORT .................. 6-1

Reference ....... . . . . . . . . . . . . . 6-2

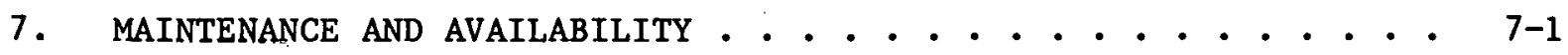

7.1 Effects of Fission Product Activity on Maintenance . . . 7-1

7.2 Comparison of Scheduled Outage Requirements . . . . . . . 7-4

References ....................... . 7-9

8. SAFETY ASPECTS OF PBR AND PRISMATIC COMPARISON . . . . . . . 8-1

8.1 Accident Risk Comparison ............... . . 8-1

8.1.1. Earthquakes . . . . . . . . . . . . 8-1

8.1.2. Depressurizations ............. . 8-5

8.1.3. Spent Fuel Handling Accidents... . . . . . . 8-6

8.1.4. Water Ingress . . . . . . . . . . . 8-6

8.1.5. Core Heatup ................. . . $8-7$ 
8.2 Circulating Activity . . . . . . . . . . . . 8-10

References .................... . 8-13

9. PCRV DIMENSIONS .. . . . . . . . . . . . . . 9-1

Reference ....................... 9-1

10. FUEL REPROCESSING COST ESTIMATE . . . . . . . . . . . . 10-1

FIGURES

4-1. Comparison of prismatic fuel HTGR and PBR volume-temperature

distribution $\left(850^{\circ} \mathrm{C}\right)$................ . . 4-5

7-1. HTGR-SC 900-MW(e) plant, typical annual refueling outage flow chart.................... . . . 7-5

7-2. Summary of scheduled outage requirement estimate for HTGR and PBR ... . . . . . . . . . . . . . . . . . 7-8

TABLES

2-1. Prismatic and pebble bed HTR core status . . . . . . ... . 2-2

4-1. Prism/pebble bed fuel performance comparison, $700^{\circ} \mathrm{C}$ steam cycle ..................... . . 4 4-7

4-2. Prism/pebble bed fuel performance comparison, $850^{\circ} \mathrm{C}$ gas turbine ...................... . 4-8

4-3. Prism/pebble bed fuel performance comparison, $950^{\circ} \mathrm{C}$ process heat................... . . 4-10

7-1. Summary of planned maintenance activities for representative HTGR-SC with respect to effect of fission product retention of fuel ...................... 7-3

8-1. Safety comparison of pebble bed and prismatic core accident analysis....................... 8-2

8-2. Comparison of offsite doses and containment access during normal operation for pebble bed and prismatic core . . . . . . . 8-12

9-1. PCRV däta . . . . . . . . . . . . . . . 9-2

10-1. Preliminary comparison of prism/pebble bed reactor cycle characteristics .. . . . . . . . . . . . 10-3

10-2. Reprocessing plant design basis (annual throughput) . . . . . 10-4

10-3. Reprocessing plant unit cost basis HEU fuel recycie . . . . 10-6 


\section{INTRODUCTION}

The Federal Republic of Germany (FRG) has developed the high-temperature gas reactor (HTR) based on a pebble bed core, while the U.S. has pursued a prismatic-fueled concept. In the course of HTR development, various U.S. and FRG participants, both private and government sponsored, have developed cooperative arrangements. During 1977, a government-to-government umbrella agreement provided for cooperation in developing one or more gas reactor concept.

In support of the 1977 cooperative discussions, U.S. contractor participants reviewed the pebble bed reactor (PBR) concept. The purpose was to provide technical and program input needed by the Department of Energy (DOE) staff for planning U.S. high-temperature gas-cooled reactor (HTGR) development and for cooperative international programs. References 1-1 and 1-2 report on evaluation results.

Since the 1977 study, U.S. HTGR development has been redirected to emphasize advanced applications, such as the direct-cycle helium gas turbine for electricity generation, and relatively high-temperature process-heat concepts. However, both sides are also actively considering processsteam-raising and cogeneration HTGR plants.

Because development objectives for the FRG PBR are similar to those for the U.S. prismatic HTGR, each concept can be considered as a technical backup to the other. An up-to-date U.S. technical understanding of the PBR concept and its potential for U.S. applications needs to be developed for further international program planning.

Participants in the FY-79 and FY-80 PBR evaluation effort include General Atumic Company (GA), Ceneral Elcctric Company (GE), Dak Ridge National Laboratory (ORNL), and Gas-Cooled Reactor Associates (GCRA). ORNL has lead responsibi.lity for the work. 
Reference 1-3 reports on GA work during FY-79. GA objectives during FY80 have been to complete detailed core performance analyses, including necessary methods development; review PBR availability with on-line refueling; assess the impact of primary circuit activity level on maintenance; review influence on safety evaluations of differences in core characteristics and performance; and provide prestressed concrete reactor vessel (PCRV) quantities and fuel reprocessing cost estimate input to ORNL. This report summarizes the FY-80 GA results through March 31, 1980 and includes conclusive comments from prior work in areas not included in FY-80 tasks. Further PBR evaluation effort is not planned during FY-80 by GA.

\section{REFERENCES}

1-1. "U.S./FRG Joint Pebble Bed Reactor Evaluation, Final Report for Fisca1 Year 1977," DOE Report GA-A14611, General Atomic Company, October 1977.

1-2. "Gas Reactor International Cooperative Program Interim Report. 5. Pebble Bed Reactor Fuel Cycle Evaluation. 6. German Pebble Bed Reactor Design and Technology Review. 7. Safety and Licensing Evaluation of German Pebble Bed Reactor Concepts," DOE Report CO0-4057 (Parts 5, 6, and 7), General Electric Company, September 1978.

1-3. "Pebble Bed Reactor Review Update, Fiscal Year 1979 Annual Report," DOE Report GA-A15687, General Atomic Company, January 1980. 


\section{SUMMARY AND CONCLUSIONS}

Both the prismatic fueled HTGR and pebble-bed high-temperature gascooled thermal reactor (HTR) concepts currently under development employ inert helium coolant and graphite fuel/reflector systems. These common features offer high gas temperature capability, good neutron economy relative to the light water reactor (LWR), and large core thermal safety margins. However, basic differences in the fuel element geometry between the PBR and the prismatic HTGR give each unique performance characteristics and design differences.

GA attempted to quantify the claimed PBR concept advantages of lower fuel temperature and therefore reduced fission product release and of improved availability with on-line refueling. GA also generally assessed the PBR unique problem areas, particularly control and shutdown systems and reactor internals structures. GA considered PBR safety and maintenance characteristics relative to the extensive HTGR information base in these areas. Table 2-1 summarizes the GA assessment of the technical status of the two concepts. Note that the prismatic fueled HTGR has a substantially greater large-scale reactor operating experience.

The GA evaluation independently confirmed the FRG-claimed low maximum fuel temperatures and associated fission product release for the PBR concept, particularly for higher temperature applications. Evaluation of availability indicates that maintenance and in-service inspection (ISI), rather than refueling, control reactor outage time. Thus, on-line refueling of the PBR offers no availability advantage.

Even though GA did not develop detailed nuclear island cost estimates, when PCRV dimensions and quantities and the required number of control rod 
TABLE 2-1

PRISMATIC AND PEBBLE BED HTR CORE STATUS

\section{Prismatic Core}

Reactor programs

Fuel management

Fuel element demonstration

Control and shutdown

Primary control

Backup shutdown $1 / 3$ core annually.
330-MW(e) Fort St. Vrain (FSV) in operation since 1976 , up to $70 \%$ power.

40 MW(e) Peach Bottom (PB) Unit No. 1. 1967 to 1974 . Now decommissioned.

20-MW( $t$ ) DRAGON operated in United Kingdom from 1965 to 1976.

Graded-cycle, off-line refueling, $1 / 4$ to

Full exposure fuel components in capsul tests and PB (particles, fuel rods, and graphite).

Partial life integral fuel element experience in FSV.

Gravity control rods into in-core channels. Full-scale operating experience in reactor environment of $\mathrm{FSV}$ and $\mathrm{PB}$.

Gravity feed absorber granules into incore channels. Full-scale experience in reactor.environment of FSV.

\section{Pebble Bed Core}

300-MW(e) Thorium Hochtemperatur Reaktor (THTR) under construction in FRG (1985 expected operation).

15-MW(e) Arbeitsgemeinschaft Versuch Reaktor (AVR) in operation at Kernforschungsanlage (KFA), FRG. 1967 to present. (2.2 MW/ $\mathrm{m}^{3}$ power density).

Once-through-then-out (OTTO), on-line fueling, 3+ year-fuel lifetime.

Fuel, elements tested to full exposure in test reactor rigs.

Low power density, full-life core experience in AVR.

THTR under construction.

High-thrust rigid control rods drive into pebble bed. Development testing in room temp. air up to full scale. THTR experience not available until 1985. Only reflector rods in AVR.

Gravity feed absorber spheres ( $1 / 6$ fuel elenent diam) into interstices between fuel elenents (KLAK). Air testing in partial core mockup silo using steel or graphite absorber sphere mockups. Conflicting requirements of easy removal with stable retention during seismic event. 


\section{Prismatic Core}

Reflector and core support ments are replaced during normal refueling.

Extensive selsmic testing and analytical model development provide design basis.

Thermal stresses are larger in region size prismatic core support blocks due to hot sireaks caused by power tilts.

On-line-coolant flow orifices provide power-flow matching for radial power distration:

In-core instrumentation provides pover distribution data throughout core.

Age-peaking tilts within refueling regions result in flow-power mismatches and increased local fuel temperatures. Maximinn calculated fuel tenperature about $1300^{\circ} \mathrm{C}$ for $950^{\circ} \mathrm{C}$ core exit temperature, assuming 10-row block.

Local core helium temperature fluctuations osserved in FSV under sertain conditions. A design $\mathrm{fix}$ has been leveloped and installed. Future HTG? cores are structurally more constrained.

\section{Pebble Bed Core}

Core-adjacent reflectors difficult to replace. Local degradation of top and upper side reflector expected due to high fluence exposure during life. Predicted that replacement will be required.

Reflector and core support gaps must be controlled to prevent intrusion of pebble debris or KLAK.

Radial compression force requirements on side reflector and core support to prevent gap formation limits allowance for thermal expansion relative to boundary structure.

Seismic displacement of core/reflector array relative to PCRV difficult to accommodate by high thrust control rods and fuel discharge channels.

On-line coolant flow orificing is not provided and does not appear necessary.

Favorable radial power distribution results in small exit coolant tenperature range.

Core instrumentation must all be external to active core.

Radial flow-power mismatches increase nominal maximum fuel temperature. Maximum FRG calculated fuel temperature $\sim 1100^{\circ} \mathrm{C}$ for $950^{\circ} \mathrm{C}$ core exit temperature. 


\section{$\underline{\text { Prismatic Core }}$}

Core performance (cont'd)

Safety

Avallability

In-service inspection
Locally higher fuel temperatures result in higher predicted fission product release.

Maximum fuel element stresses caused by fluence and temperature gradients within elements and are additive to stresses caused by seismic impacts.

Can insert full cold shutdown rod worth from hot, full-power conditions.

Closed end channels more likely to contain slumped absorber in-core during core core heatup accident.

Periodic refueling outage required. Inspection and planned maintenance performed concurrently.

Reflector and core support structures can be routinely inspected during refueling.

\section{Pebble Bed Core}

Lotver peak fuel temperatures offer improved fuel performance and lower fisston product release.

Maximum fuel element stresses believed caused by control rod insertion forces. A certain amount of fuel element breakup is expected.

Can achieve hot subcritical in scram from hot, full-pover conditions.

Core coolant pressure drop with KLAK in place expected to significantly increase head requirement for core auxiliary cooling system.

Lower initial graphite and fuel temperatures do not appear to of $f$ er a significant advantage in a core heatup accident.

Top reflector collapse appears probable during a core heatup accident.

Licensing of a large PBR has not yet been completed. THTR licensing is still in progress.

Does not require refueling outage. Maintenance and inspections requiring shutdown need to be accommodated. Extended outage may be required once or twice in life for reflector replacement. No avallability advantage over prismatic system is projected

May not be feasible to inspect core support structure without core removal. Anticipate Nuclear Regulatory Commission (NRC) requirement for core support inspection. 
mechanisms are compared, they indicate higher plant capital costs for the PBR. Fuel cycle costs are estimated to be essentially the same for the two concepts (Ref. 2-1).

The PBR normal operating and accidental depressurization conditions show somewhat improved fuel performance and reduced fission product release, but the differences may not offer significant safety or economic advantages. On the other hand, the lack of licensed and demonstrated large PBR shutdown control systems, the unresolved reflector graphite and reactor internals structural uncertainties, and the anticipated plant cost penalties introduce new programmatic and economic risks to any potential U.S. program adopting the PBR concept. For future very high temperature applications, above $900^{\circ} \mathrm{C}$ core exit temperature, the added PBR fuel performance margins may be more significant and should be better defined relative to the prismatic HTGR for specific applications and licensing requirements. Programmatic risks may also be reduced if FRG PBR development results and operating experience are positive in the meantime.

REFERENCE

2-1. "Pebble Bed Reactor Review Update, Fiscal Year 1979 Annual Report," DOE Report GA-A15687, General Atomic Company, January 1980. 


\section{REACTOR OPERATING EXPERIENCE}

\subsection{PRISMATIC}

The 115-MW(t) Peach Bottom Atomic Power Station, Unit No. 1, was the first U.S. HTGR installation. This 40-MW(e) prototype power plant operated successfully on the Philadelphia Electric system from its 1967 commercial startup until its late 1974 shutdown, when it was subsequently decommissioned. The unit demonstrated a high lifetime availability of $88 \%$ and excellent maintenance access due to very low primary system radioactivity. Power density was $8.3 \mathrm{MW} / \mathrm{m}^{3}$; reactor outlet helium temperature was $\sim 700^{\circ} \mathrm{C}$; and fuel lifetime in the batch-reloaded core was three years. The cylindrical sleeve fuel elements, although differcnt geometry than the later adopted hexagonal block elements, demonstrated technical performance of a coated particle and graphite structure prismatic fuel concept.

Electricity generation from the larger 330-MW(e) Fort St. Vrain (FSV) HTGR demonstration power plant began in 1ate 1976. The unit has since operated at up to $70 \%$ power on the Public Service Company of Colorado system and has generated more than $10^{9} \mathrm{kWh}$ of electricity. Power operation has been limited to $70 \%$ by the Nuclear Regulatory Commission (NRC), pending resolution of local core temperature fluctuations occurring under certain operating conditions. A design fix in the form of core restraint devices has been developed, tested, and installed. The reactor has returned to power operation, and further testing is planned.

Power density of the FSV unit is $6.3 \mathrm{MW} / \mathrm{m}^{3}$; reactor outlet helium temperature is $785^{\circ} \mathrm{C}$; and fuel life is six years, with one-s1xth of the core replaced annually. The first refueling was recently successfully completed and the unit returned to service. Fission product activity in the primary circuit has remained low, with better than expected fuel performance. Maintenance work on a helium circulator removed during the refueling outage was 
performed under direct contact conditions without decontamination. Extensive inspections of the reactor internals and selected fuel elements were also. conducted during the refueling outage. No degradation or damage of any kind was observed. A surveillance fuel element has been returned to GA for more detailed postirradiation examination.

The 20-MW( $t$ ) DRAGON reactor, brought to full power operation in mid1965, was constructed in the United Kingdon (U.K.) to demonstrate the principles on which the HTR is based and to undertake research and development (R\&D) for evolving the commercial HTR. Primary emphasis was given to fuel and fuel element testing. During more than 2000 days of nominal full power, considerable HTR fuel and graphite performance experience was accumulated. Primary circuit activity was low throughout the operating period, even though many advanced and purposefully over-driven fuel elements were operated in the core. A program highlight was the easy component access and handleability during maintenance because of low contamination levels.

\subsection{PEBBLE BED}

The 40-MW( $t$ ) Arbeitsgemeinshaft Versuch Reaktor (AVR) achieved power operation in 1967 and generates $15 \mathrm{MW}(\mathrm{e})$. This test unit is located at the Kernforschungsanlage Jülich GmbA (KFA) Nuclear Research Center, FRG. Power density is $2.2 \mathrm{MW} / \mathrm{m}^{3}$ (approximately one-third of the Peach Bottom and FSV values); reactor outlet helium temperature since 1974 has been $950^{\circ} \mathrm{C}$, after operating earlier at $850^{\circ} \mathrm{C}$; and refueling has been on line. Lifetime availability of the AVR was believed to be over $80 \%$ prior to the water ingress incident in May 1978. The fuel management scheme involves multiple passes of each fuel sphere through the core to achieve full exposure. Fission product activity in the primary circuit has typically remained low during operation, confirming expected fuel particle integrity. Examination of full burnup fuel has further confirmed fuel particle and fuel sphere integrity. Control rods operate in the reflector and therefore do not penetrate the pebble bed in the AVR. Thus, operating reactor experience with control rod insertion into the pebble bed is not available from the AVR. 
A demonstration plant, the 750-MW( $t$ ), 300-MW(e) Thorium Hoch Temperatur Reaktor (THTR) is under construction near Schmeshausen and when completed will operate on the German utility VEW ${ }^{*}$ system. Power density is $6 \mathrm{MW} / \mathrm{m}^{3}$; core exit coolant temperature will be $750^{\circ} \mathrm{C}$; and refueling will be on-line with a multiple-pass management similar to AVR. The THTR will offer the first operating reactor experience with direct insertion of control rods into the bed under hot hellum conditions. Operation is currently estimated to commence in 1985. Licensing difficulties account for most of the delay.

\footnotetext{
${ }^{*}$ Vereinigte Elektrizitatswerke Westfalen AG (private utility in Dortmund, FRG).
} 


\section{CORE PERFORMANCE ASSESSMENT}

\subsection{GENERAL}

HTR core design limits typically evolve from long-term processes, such as temperature-dependent diffusion of certain fission products through the pyrocarbon coatings on the coated fuel particles, chemical corrosion by fission products, fuel metals of pyrocarbon, or silicon carbide barrier layers in the fuel particle coatings, or distortion of graphite fuel element components due to high fast neutron fluence exposure.

Extensive worldwide irradiation and laboratory tests have provided design performance models for HTGR fuel particles (Ref. 4-1). Using these models, core parameters are established to assure that fuel performance and fission product release satisfy design criteria for the application. Operating results from the 115-MW( $t$ ) Peach Bottom No. 1 HTCR, the 842-MW( $t$ ) Fort St. Vrain, and European HTR experience with the 20-MW( $t$ ) DRAGON reactor and the 40-MW( $t$ ) AVR have also confirmed fuel performance and core design methods.

HTGR core design results and experience make evident that performance characteristics of both prismatic and pebble bed cores depend upon appropriately selecting controlling parameters, including coolant temperature, fuel lifetime, fast neutron exposure, fuel element configuration, reactor control, fuel cycle management, fuel particle type, and particle coating design.

Performance evaluations of low-enriched uranium (LEU)/thorium cores (up to $20 \%$ enrichment) and high-enriched uranium (HEU)/thorium designs ( $93 \%$ enrichment) have been performed for both pebble bed and prismatic fuel concepts. To study the pebble bed cores, physics, fuel performance, and fission product release methods were adapted from existing prismatic methods. For 
thermal-flow analysis, the PEBBLE code (Ref, 4-2) developed at Los Alamos Scientific Laboratory (LASL) was modified and adapted to the GA core analysis code systems.

\subsection{PHYSICS}

GA performed preliminary equlibrium physics design studies of several PBR cores. The studies included two reactor sizes with core power ratings of 1000 and $3000 \mathrm{MW}(t)$.' An LEU/Th fuel cycle was used in the 1000-MW(t) core. For the larger core, both HEU/Th and LEU/Th fuel cycles were evaluated. The physics performance of the $3000 \mathrm{MW}(\mathrm{t})$ core with HEU/Th fuel was compared with a previously documented FRG design study of essentially the same core (Ref. 4-3).

This report presents studies that are part of the overall PBR evaluation program. These studies provide a preliminary, independent evaluation of the time-invariant physics performance of PBR cores. The main observations from these studies are the following:

1. Excellent radial power density flattening was achieved with two radial feed loadings, confirming published FRG radial power profiles.

2. Axial power shapes are steeper for the core with HEU fuel than the same core with LEU/Th fuel. In both cases, the once-through-thenout (OTTO) cycle naturally produces the steep axial power shape needed to minimize peak fuel temperatures.

3. Neutron leakage out of proposed pebble bed cores is considerably greater than that of similar sized prismatic type cores, primarily into the void on top of the core. This void leakage appears to improve axial and radial power distributions. 
4. Criticality is achieved in both the 1000- and 3000-MW( $t$ ) PBR cores with either LEU/Th or HEU fuel cycles (without exceeding a $20 \%$ particle packing fraction limit), based on the OTTO cycle with continuous refueling.

5. GA has well-documented design methods and codes verified against published results for the physics design analysis of pebble bed cores.

GA did not perform studies of control rod worth and overall reactivity control.

\subsection{THERMAL-HYDRAULIC}

Thermal-hydraulic studies included the two reactor sizes with core ratings of $3000-$ and $1000-\mathrm{MW}(t)$, HEU and LEU fuel cycles, and helium heating conditions of $507^{\circ}$ to $850^{\circ} \mathrm{C}, 427^{\circ}$ to $850^{\circ} \mathrm{C}$, and $300^{\circ}$ to $950^{\circ} \mathrm{C}$. Thus, thermal-hydraulic performance of $\mathrm{PBRs}$ can be compared for different core sizes, fuel cycles, and helium heating conditions.

The following conclusions can be made from the thermal-hydraulic study of PBRs:

1. Based on FRG data indicating relatively uniform ball packing density, the helium flow is mainly axial and parallel.

2. Radial heat transfer in the fluid and solid phase is significant, and therefore the radial temperature distribution is flatter than the radial power distribution. This is more prominent in the smaller 1000-MW core, where the radial power shape is more highly distorted near the side reflector. 
3. Differences between the peak and the minimum in the radial. temperature distribution are sma1l, mainly due to the relatively flat radial power distributions. The radial temperature variation in the exit gas temperature at core outlet is only $20^{\circ}$ to $50^{\circ} \mathrm{C}$ for all the reactor design cases considered in this study (i.e., nominal, unrodded steady-state full-power conditions).

4. The core has nearly ideal fuel temperature volume distribution. The maximum fuel temperature is $100^{\circ}$ to $170^{\circ} \mathrm{C}$ above the core average exit gas temperature, and most of the core volume is near the maximum fuel temperature (see Fig. 4-1).

5. The core pressure drop through the pebble bed is large and varies from 0.5 to 1 bar ( 7 to 14 psi) for the various core designs considered (i.e., approximately a factor of two higher than the core pressure drop in an HTGR under similar flow conditions).

6. Thermal-hydraulic calculations indicate that a two-dimensional heat transfer model is necessary to get accurate results in regions of radial zone or reflector interfaces.

7. Comparison of the heat transfer characteristics of the pebble and prism fuel concepts shows no significant overall heat conductance advantage for the pebble bed system. The larger pebble surface heat transfer area and higher coolant-to-surface heat transfer film coefficient for the pebble bed are completely offset by the higher solid conductance characteristic of the prismatic geometry. Therefore, the fuel temperature performance advantages of the PBR can be almost totally attributed to the radially flat power distribution and nearly ideal axial power shape achieved by the continuously fueled OTTO fuel management cycle. 


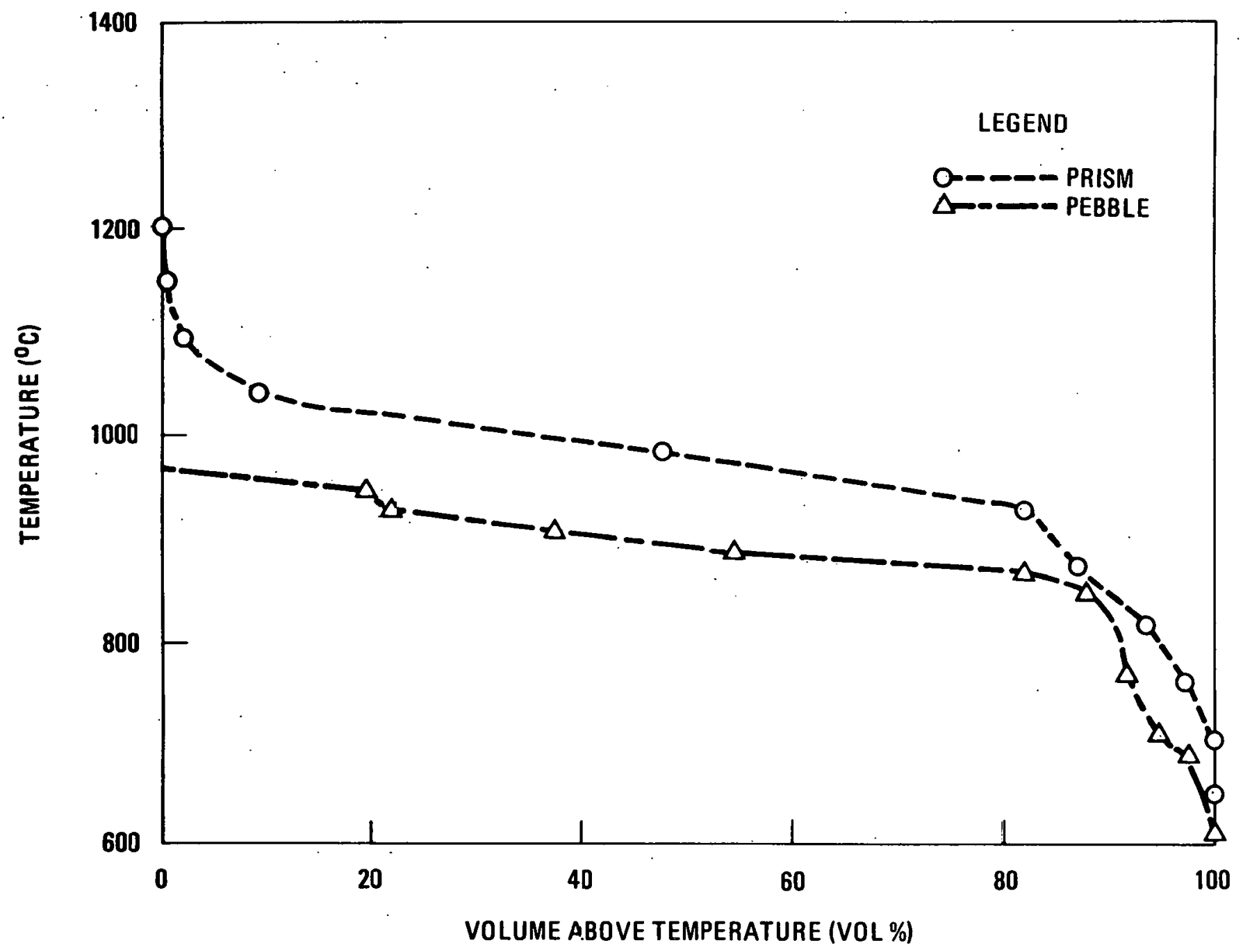

Fig. 4-1. Comparison of prismatic fuel HTGR and PBR volume-temperature distribution $\left(850^{\circ} \mathrm{C}\right)$ 


\subsection{FUEL PERFORMANCE AND FISSION PRODUCT RELEASE}

Based on the physics and thermal-hydraulic analyses results, fuel particle performance and fission product release were estimated for the PBR cores using GA fuèl performance models and calculational methods. Similar, but not identical, prismatic core fuel performance cases were compared. Power density, pressure drop allocated to the core, and fuel management parameters are different for the pebble and prism cases, but the cores compared typically represent reference designs for the applications considered.

Tables 4-1 and 4-2 summarize calculated particle fallure fractions and representative gaseous $(\mathrm{Kr}-88)$ and plateout ( $\mathrm{Cs}-137)$ fission product release values for steam cycle $\left(700^{\circ} \mathrm{C}\right)$ and gas turbine electricity generating plant conditions $\left(850^{\circ} \mathrm{C}\right)$, respectively.: As shown by the tables, fuel particle failúre differences are small, with the PBR being slightly lower when the same particle type is used in both cores. This coupled with lower fuel temperatures in the PBR results in about a factor of two less gaseous circulating activity release from the PBR core. Since a prismatic-fuel HTGR steamcycle case was not available with TRISO-coated fertile particles, a BISOcoated fertile particle case was selected. Therefore, when fertile particle failure for the steam cycle case shown in Table 4-1 is compared, any conceptrelated differences are exaggerated.

Differences in metallic fission product release are larger than gaseous release because lower graphite temperatures in the PBR result in greater attenuation of fission metals by the graphite due to the strong temperature dependence of diffusion and sorption of metallic species in graphite. However, within the range of fission product release predicted for the two core concepts, significant technical or economic advantage cannot be clearly established for the somewhat lower levels achieved by the PBR. Maintenance and safety reviews summarized in subsequent sections indicate that much lower levels would need to be achieved to ellminate all component shielding and to allow contact maintenance. Moreover, limiting accident doses are not reached until much higher release levels occur. Operationally, gaseous-activityrelated limits more likely to be controlling. In these cases, doses are 
TABLE 4-1

PRISM/PEBBLE BED FUEL PERFORMANCE COMPARISON, $700^{\circ} \mathrm{C}$ STEAM CYCLE

\begin{tabular}{|c|c|c|c|}
\hline \multirow[b]{2}{*}{ Parameter } & \multirow[b]{2}{*}{ Pebble Bed } & \multicolumn{2}{|c|}{ Prism } \\
\hline & & 10-Row Block & 8-Row Block \\
\hline \multicolumn{4}{|l|}{ Fissile Failure (\%) } \\
\hline Defects & 0.070 & 0.072 & 0.072 \\
\hline Pressure vessel & 0.007 & 0.008 & 0.012 \\
\hline Kernel migration & -- & -- & -- \\
\hline SiC corrosion & -- & -- & -- \\
\hline Tota 1 & 0.077 & 0.080 & 0.085 \\
\hline \multicolumn{4}{|l|}{ Fertile Failure (\%) } \\
\hline Defects & 0.061 & $0.023(a)$ & $0.023(a)$ \\
\hline Pressure vessel & -- & 0.088 & 0.090 \\
\hline Kernel migration & -- & -- & - \\
\hline SiC corrosion & -- & - & -- \\
\hline Total & 0.061 & 0.111 & 0.113 \\
\hline \multicolumn{4}{|c|}{ Kr-88 Circulating (Ci/MW) } \\
\hline Nominal & 0.15 & 0.25 & 0.38 \\
\hline $100 \%$ hydrolysis & 0.38 & 1.22 & 1.85 \\
\hline \multicolumn{4}{|c|}{ 40-yi Plateout ( $\mathrm{Ci} / \mathrm{MW}$ ) } \\
\hline Cs -137 & 0.06 & 1.16 & 3.4 \\
\hline Sr-90 & 0.01 & 0.04 & -- \\
\hline
\end{tabular}

(a) BISO fertile particle for prism. 
TABLE - 4-2

PRISM/PEBBLE BED FUEL PERFORMANCE COMPARISON, $850^{\circ} \mathrm{C}$ GAS TURBINE

\begin{tabular}{|c|c|c|c|}
\hline & Parameter & Pebble Bed & $\begin{array}{c}\text { Prism } \\
(10-\text { row block })\end{array}$ \\
\hline \multicolumn{4}{|c|}{ Fissile Failure (\%) } \\
\hline & Defects & 0.071 & 0.072 \\
\hline & Pressure vessel & 0.011 & 0.015 \\
\hline & Kernel migration & -- & -- \\
\hline & SiC corrosion & -- & 0.004 \\
\hline & Total & 0.082 & 0.091 \\
\hline & \multicolumn{3}{|l|}{ Fertile Failure (\%) } \\
\hline . & Defects & 0.061 & 0.060 \\
\hline & Pressure vessel & 0.001 & 0.002 \\
\hline \multirow[t]{9}{*}{$\therefore$} & Kernel migration & -- & -- \\
\hline & SiC corrosion & -- & -- \\
\hline & Total & 0.062 & 0.062 \\
\hline & $\mathrm{Kr}-88$ Circulating ( $\mathrm{Ci} / \mathrm{MW})$ & & . \\
\hline & Nominal & 0.28 & 0.41 \\
\hline & $100 \%$ hydrolysis & 0.73 & 1.34 \\
\hline & 40-yr Plateout ( $\mathrm{Ci} / \mathrm{MW})$ & & \\
\hline & $\mathrm{Cs}-137$ & 3.3 & 14.7 \\
\hline & $\mathrm{Sr}-90$ & 0.02 & 0.04 \\
\hline
\end{tabular}


dependent on circulating gaseous activity and are a function of the PCRV primary helium coolant leak rate and of the containment ventilation flow. Differences between the prismatic core and PBR are smallest for gaseous circulating activity.

For very high temperature applications, above $900^{\circ} \mathrm{C}$ core exit temperature, the PBR fuel performance advantage is expected to increase; however, prismatic fuel design and fuel management optimization for the more advanced conditions is expected to result in plants capable of meeting economic and safety criteria. Table 4-3 summarizes fuel particle failure and fission product release for a $950^{\circ} \mathrm{C}$ core exit temperature application based on a threeyear prismatic fuel replacement schedule. Two HTGR cases are shown. The first column tabulates results using the current model for fission product palladium corrosion of the SiC fissile particle coating layer. This model is believed to be very conservative, based on more recent longer term data. The anticipated model corrections yleld the results tabulated in the second column.

REFERENCES

4-1. Gulden, T. D., et al., "Coated Particle Fuels," Nucl. Technol. 35, No. 2 (1977) (Special Issue on Coated Particle Fuels).

4-2. Stroh, K. R., "Thermal-Hydraulic Analysis Techniques for Axisymmetric Pebble Bed Nuclear Reactor Cores," Los Alamos Sclentific Laboratory Report LA-7709-T, March 1979.

4-3. "U.S./FRG Joint Pebble Bed Reactor Evaluation, Final Report for Fiscal Year 1977," DOE Report GA-A14611, General Atomic Company, October 1977. 
TABLE 4-3

PRISM/PEBBLE BED FUEL PERFORMANCE COMPARISON, $950^{\circ} \mathrm{C}$ PROCESS HEAT

\begin{tabular}{|c|c|c|c|}
\hline \multirow[b]{2}{*}{ Parameter } & \multirow[b]{2}{*}{ Pebble Bed } & \multicolumn{2}{|c|}{$\begin{array}{c}\text { Prism (10-row block) } \\
3-Y r\end{array}$} \\
\hline & & old PD & Rev PD \\
\hline Fissile Failure (\%) & . & . & \\
\hline Defects & 0.071 & 0.073 & 0.073 \\
\hline Pressure vessel & 0.016 & 0.035 & 0.035 \\
\hline Kernel migration & -- & -- & -- \\
\hline SiC corrosion & -- & 0.379 & 0.020 \\
\hline Total. & 0.087 & 0.488 & 0.128 \\
\hline Fertile Failure (\%) & & & \\
\hline Defects & 0.061 & 0.058 & 0.058 \\
\hline Pressure vesse1 & 0.001 & 0.004 & $0.004^{\circ}$ \\
\hline Kernel migration & -- & -- & -- \\
\hline SiC corrosion & -- & -- & -- \\
\hline Total & 0.062 & 0.062 & 0.062 \\
\hline $\mathrm{Kr}-88$ Circulating ( $\mathrm{Ci} / \mathrm{MW}$ ) & & & . \\
\hline Nominal & 0.34 & 0.68 & 0.57 \\
\hline $100 \%$ hydrolysis & 1.14 & 4.25 & 1.61 \\
\hline 40-yr Plateout ( $\mathrm{C} i / \mathrm{MW})$ & & & \\
\hline Cs -137 & 7.0 & 78.4 & 20.9 \\
\hline $\mathrm{Sr}-90$ & 0.03 & -- & - \\
\hline
\end{tabular}




\section{CORE CONTROL AND SHUTDOWN}

Structural designs with channels into the pebble bed core to insert control rods have not been found to be practical. Several major expected problems are (1) the channels would disrupt pebble flow uniformity, (2) they would increase core voidage and, therefore, increase neutron leakage and coolant bypass flow along the channel walls, and (3) horizontal components of pebble motion through the bed could create high horizontal displacement force on the channel tubes. High temperatures and high fast neutron exposure would limit life such that periodic replacement would be required.

Both the U.S. and the FRG have worked on annular core configurations, but little information is available on the concept. In this case, inner and outer reflector control rods in channels would increase worth over outer reflector rods only. Practicality of this concept remains unconfirmed.

Since control rod channels cannot be provided in core, high thrust forces or rotational drives are required to insert rods into the pebble bed. This results in high local forces on individual fuel elements contacting the rods during insertion and significant upward displacement of some fuel elements if rotating rods are employed. The control rods are also in direct thermal contact with the fuel balls and core coolant when inserted. During a scram, they experience high temperature conditions, particularly in the process heat reactor. Temperature and structural loads on the rods increase as insertion progresses. As a result, the initial depth of insertion into the hot core is limited by control rod structural considerations. The rod system must be designed to the opposing requirements of ensuring an effective scram yet not exceeding the strength limits of the rods at high temperature. As cooldown proceeds following initial subcriticality, further insertion can take place. In addition, the mechanics of control rod insertion during an earthquake have not been addressed at this stage of the design. Since the THTR is not yet operational, experience is not yet available on control rod 
insertion in the reactor environment, nor are data available on fuel element mechanical failure under actual reactor conditions with repeated control rod insertion into the pebble bed.

A reserve shutdown system has been proposed for the pebble bed core, the so-called KLAK system, which consists of $\sim 9-\mathrm{mm}-\mathrm{diam}$ boron-carbide/graphite spheres. When these spheres are dropped onto the core, they flow into the spaces between the fuel balls to provide the required long-term shutdown capability. The KLAK system represents a difficult design challenge, since it must be readily removable, yet must remain stably in the core when in use, including during seismic conditions.

Avoiding control rod insertions under normal operation is preferable because of potential clad temperature problems and possible fuel pebble breakage. Thus, control rods operating only in the upper void have been proposed. High axial neutron leakage from the core is required. for this approach to be effective.

The curtain of operational control rods located in the void above the core shields the out-of-core neutron detectors located in the upper PCRV (incore detectors are not feasible in a pebble bed core). This location may prevent easy detection of xenon power oscillations and may mean that stuck rods, accidental rod insertion, or local power peaks cannot be seen, since the detectors will effectively see only a smeared-out flux from a wide area of the core.

In-core flux or temperature sensors to confirm reactor power and/or power-to-flow conditions within the active core cannot be provided. Xenon oscillations and control of outlet gas temperature could also be a problem.

GA has performed only limited detailed independent evaluation work on reactor control and stability. References 5-1, 5-2, and 5-3 report on work performed. 


\section{REFERENCES}

5-1. "U.S./FRG Joint Pebble Bed Reactor Evaluation, Final Report for Fiscal Year 1977," DOE Report GA-A14611, General Atomic Company, October 1977 .

5-2. "Pebble Bed Reactor Review Update, Fiscal Year 1979 Annual Report," DOE Report GA-A15687, General Atomic Company, January 1980.

5-3. Baxter, A. M., and E. O. Winkler, "Pebble Bed HTR Review Update Trip Report -Visit to FRG -March 17 through 28, 1979," General Atomic Company unpublished data, April 27, 1979. 


\section{REFLECTOR AND CORE SUPPORT}

Because the reflectors provide structural containment of the fluid-like core, replacing adjacent reflector elements with the core in place may not be practical. In any event, reflector replacement would involve a major outage and will require equipment similar but likely more complex than prismatic core refueling machinery. Therefore, the FRG program has an objective of developing reflector materials and designs capable of remaining in place for the entire plant life. Even so, replacement capability must be a design feature. GA concludes that no alternative to replacement has been sufficiently developed.

With the relatively low power density pebble bed core designs $(5.5$ $\mathrm{MW} / \mathrm{m}^{3}$ ) employing the OTTO cycle, 30-year fast neutron exposure to maximum exposure reflector elements is estimated to reach $4 \times 10^{22}$ equivalent dido nickel (EDN). For expected operating temperatures, local expansive degradation of core grade nuclear graphite is predicted to occur below this endof-1ife exposure. One FRG proposed design solution was to configure adjacent reflector elements in the high fluence regions such that local cracking of the graphite can be accepted. The geometry must be such that any pieces falling off would not impede pebble flow, and the fragments must be small enough to be sorted out by the fuel sphere handling devices. The fuel sphere handling system can sort and remove failed spheres. Also, the impact on dust levels, reflector integrity, and core ball flow would have to be assessed.

Very high cost, stable graphites (costing 10 to 20 times that of core grade nuclear graphite) might offer a solution, but structural engineering designs and performance evlauations have not been developed to support assessment of this alternative.

Equivalent hydrostatic bed forces are large on the slde and bottom reflector/core support components. Radial spring packs must absorb total 
differential motion between the thermal shield (or liner) and graphite array while maintaining aximuthally uniform compressive loading. Thermal cycling and friction may create local gap accumulations allowing pebble, KLAK, or reflector debris to intrude between blocks, creating high local stresses and binding of the array. Complete structural solutions have not yet been established. Also, response of the reflector and core support is uncertain for seismic conditions specified for U.S. applications. The need for radial compressive springs to restrain the array appears to conflict with the need for small displacements during a seismic event to avoid damage and shear failure of the fuel discharge channel structures beneath the core.

ISI of the core support structure may not be feasible without core removal. The U.S. NRC is anticipated to require core support inspection.

The PBR also appears to be vulnerable to objects falling into the pebble bed core (e.g., determining that a piece of top reflector has fallen onto the bed may be difficult). If undetected, the top reflector piece, or possibly a broken control rod, then becomes submerged and may ultimately plug a fuel discharge channel. Location and removal appear difficult.

Reference 6-1 reports on the GA technical review of the PBR reflector and internals structures and initial seismic response assessment.

\section{REFERFNCE}

6-1. "Pebble Bed Reactor Review Update, Fiscal Year 1979 Annual Report," DOE Report GA-A15687, General Atomic Company, January 1980. 


\section{MAINTENANCE AND AVAILABILITY}

\subsection{EFFECTS OF FISSION PRODUCT ACTIVITY ON MAINTENANCE}

GA studied whether relative HTGR primary circult cleanliness (for a range of clean to dirty fuel) significantly affects plant avallability, with respect to fission product activity, and whether the PBR and prismatic-fueled reactor react differently to cleanliness.

The study focused on scheduled maintenance and inspection activities rather than forced outage (unscheduled malntenance). Specifically, those requirements that have been previously stipulated and examined for time requirements for reference high-temperature gas-cooled reactor steam cycle (HTGR-SC) plants (Ref. 7-1) were used as the study reference base. Simllar requirements for the high-temperature gas-cooled reactor gas turbine (HTGRGT) were also reviewed. Table 4-1 shows the circuit contaminant level used as the base case under Prism 8 row block. References 7-2 through 7-5 present information on the accessibility and radiation exposure rate limitations for HTGR variants and analytical base variations. The effect of relative circuit cleanliness was examined by considering the effect of varying the circuit circulating and plateout inventories to $1 / 10,10$, and 100 times the base case values.

Discussions were held with personnel responsible, respectively, for assessing maintenance/ISI, shielding and radiation protection, and fission product inventory calculations on the effects of the relative cleanliness on scheduled maintenance/ISI operations. In these discussions, each of 52 activities were examined to determine (1) where in the plant the activity is performed and whether personnel radiation exposures were limited by gas-borne contaminants, plateout, fuel element activity, or neutron activation sources within the PCRV; (2) whether the scheduled operation in the reference case is 
conducted by contact or remote maintenance; (3) whether increase or decrease in the primary circuit contamination levels would require more or less shielding and/or remote operations; and (4) whether such differences signficiantly change the activity performance time.

Table 7-1 indicates that plant availability was apparently not significantly impacted for the range of circuit cleanliness considered, although the higher activity cases could be penalized by extra performance time or personnel rotation. Decreasing the circuit contamination to $1 / 10$ apparently does not reduce time requirements because, in the base case, the HTGR already possesses high accessability and low personnel dose rates for most planned operations. Similarly, increasing the contamination by a factor of 10 impacts performance time only slightly where additional temporary shielding may have to be installed as part of maintenance. The $10 \mathrm{x}$ case was conservatively estimated to add 30 to $56 \mathrm{~h} / \mathrm{yr}$ to scheduled activities but probably not to increase annual outage time. The $10 \mathrm{x}$ case also appears to increase personnel rotation for containment access during normal operation. Because many operations can be conducted in parallel with each other and with refueling or turbogenerator maintenance, the additional time to install shielding would probably not extend the annual scheduled outage.

Increasing the contamination to 100 times the base case, however, may pose a net penalty on plant availability, because gaseous activity from assumed PCRV leakage precludes containment access normal operation. This means that on-line activities must be deferred until the annual scheduled outage. These activities add $\sim 123 \mathrm{~h} / \mathrm{yr}$ to the annual maintenance/ISI time requirements. Whether this results in a net loss of plant availability, however, again depends on the relative phasing of such jobs with others being performed during the annual scheduled outage. 
TABLE 7-1

SUMMARY OF PLAIRED MAINTENAIICE ACTIVITIES FOR REPRESEIVTATIVE HTGR-SC WITH RESPECT TO EFFECT OF FISSION PRODUCT RETENTION OF FUEL

\begin{tabular}{|c|c|c|c|c|c|c|}
\hline \multirow{2}{*}{$\begin{array}{l}\text { ISI, Test and } \\
\text { Maintenance } \\
\text { Activity }\end{array}$} & \multirow{2}{*}{$\begin{array}{l}\text { Nimber of } \\
\text { Specific ISI/ } \\
\text { Maintenance } \\
\text { Activities }\end{array}$} & \multirow{2}{*}{$\begin{array}{c}\text { Approximate } \\
\text { Time Required } \\
\text { (h/yr) Av }\end{array}$} & \multirow{2}{*}{$\begin{array}{l}\text { Controlling } \\
\text { Source of } \\
\text { Radiation }\end{array}$} & \multicolumn{3}{|c|}{ 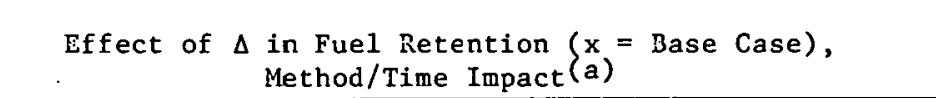 } \\
\hline & & & & $x / 10$ & $10 x$ & $100 x$ \\
\hline $\begin{array}{l}\text { Inside containment } \\
\text { during normal } \\
\text { operation }\end{array}$ & 6 & $\begin{array}{l}123 \text {, inside } \\
\text { containment }\end{array}$ & Gasborne & $\begin{array}{l}\text { None/none } \\
\text { (allows more } \\
\text { frequent access) }\end{array}$ & $\begin{array}{l}\text { Personnel } \\
\text { rotation/ } \\
\text { none }\end{array}$ & $\begin{array}{l}\text { No access/ } \\
123 \mathrm{~h} / \mathrm{yr}\end{array}$ \\
\hline $\begin{array}{l}\text { At PCRV top head } \\
\text { during shutdown }\end{array}$ & 9 & 76 & $\begin{array}{l}\text { Plateout, } \\
\text { fuel } \\
\text { activity }\end{array}$ & None/none & $\begin{array}{l}\text { Increase permanent } \\
\text { shield, remote } \\
\text { operation/none }\end{array}$ & Same as $10 x$ \\
\hline $\begin{array}{l}\text { At PCRV botton head } \\
\text { during shutdown }\end{array}$ & 10 & 115 & $\begin{array}{l}\text { Plateout, } \\
\text { meutron } \\
\text { activity }\end{array}$ & None/none & $\begin{array}{l}\text { Increase permanent } \\
\text { shield, remote } \\
\text { operations, } \\
\text { increase temporary } \\
\text { shield/14-24 } \\
\text { h/yr }\end{array}$ & Same as $10 \mathrm{x}$ \\
\hline $\begin{array}{l}\text { Steam generator, during } \\
\text { shutdown }\end{array}$ & 6 & 220 & Plateout & None/none & $\begin{array}{l}\text { Increase temporary } \\
\text { shield } / 8 \mathrm{~h} / \mathrm{yr}\end{array}$ & Same as $10 \mathrm{x}$ \\
\hline CAHE, during shutdown & 4 & 100 & Plateout & None/none & $\begin{array}{l}\text { Increase temporary } \\
\text { shield/8-16 } \\
\mathrm{h} / \mathrm{yr}\end{array}$ & Same as $10 \mathrm{x}$ \\
\hline \multirow[t]{2}{*}{$\begin{array}{l}\text { Instrumentation - At } \\
\text { varous locations. } \\
\text { Inside containment, } \\
\text { control room, etc. } \\
\text { during shutdown }\end{array}$} & 17 & 466 & Plateout & None/none & $\begin{array}{l}\text { Increase permanent } \\
\text { shield, remote } \\
\text { operations, some } \\
\text { temporary shield/ } \\
\text { small }\end{array}$ & $\begin{array}{l}\text { Same as } 10 x \\
\text { plus personnel } \\
\text { rotation. }\end{array}$ \\
\hline & 52 & $123+977$ & & & $30-56 \mathrm{~h} / \mathrm{yr}$ & $153-179 \mathrm{~h} / \mathrm{yr}$ \\
\hline
\end{tabular}

(a)

Time impact means increase or decrease in time to accomplish group of tasks; it does not necessarily mean an extension at annual szheduled dovntime. 
Predicted activity levels for all of the prismatic fuel HTGR and all but the steam cycle PBR cases presented in Section 4, Tables 4-1 through 4-3 are within the range of $x / 10$ to $10 x$ with respect to the base case HTGR-SC (Table 4-1 under Prism 8 row block). Since the PBR steam cycle is lower than $x / 10$ for cesium activity, predicted differences in fission product release between the prism and pebble bed concepts will probably not result in large differences in availability or maintenance operations.

\subsection{COMPARISON OF SCHEDULED OUTAGE REQUIREMENTS}

During 1974 to 1977 , refueling outages accounted for $\sim 40 \%$ of LWR unavailability and typically. averaged $\sim 61$ and 70 days/yr, respectively, for pressurized water reactors (PWRs) and bolling water reactors (BWRs) (Ref. 7-6). Eliminating planned refueling outages by using a reactor configuration that permits on-line refueling (i.e., with the plant producing power) has been promoted as a means to improve plant avallability. Therefore, this study was initiated to evaluate this claim.

To gain perspective on the requirements for scheduled maintenance and refueling outages, the study reviewed data compiled for operating LWRs in the U.S. These data show that much outage time, nominally labeled as refueling . outage, is for calibrating, for testing and inspecting, and for repairing or replacing failed or worn-out hardware (Ref. 7-6). These nonrefueling LWR activities would appear to be representative of those required for any large nuclear power plant licensed in the U.S. Hence, similar activities will be required for HTGRs regardless of whether refueling is done with the plant online or shut down. The prismatic fueled HTGR-SC requires reactor shutdown for refueling, while the PBR can be refueled on-line. Both, for purposes of this evaluation, are assumed to be steam cycle, electricity generating plants. Figure 7-1 shows a typical HTGR refueling outage activity flow with activity durations and sequence. This schedule provides the baseline for this availability comparison. 


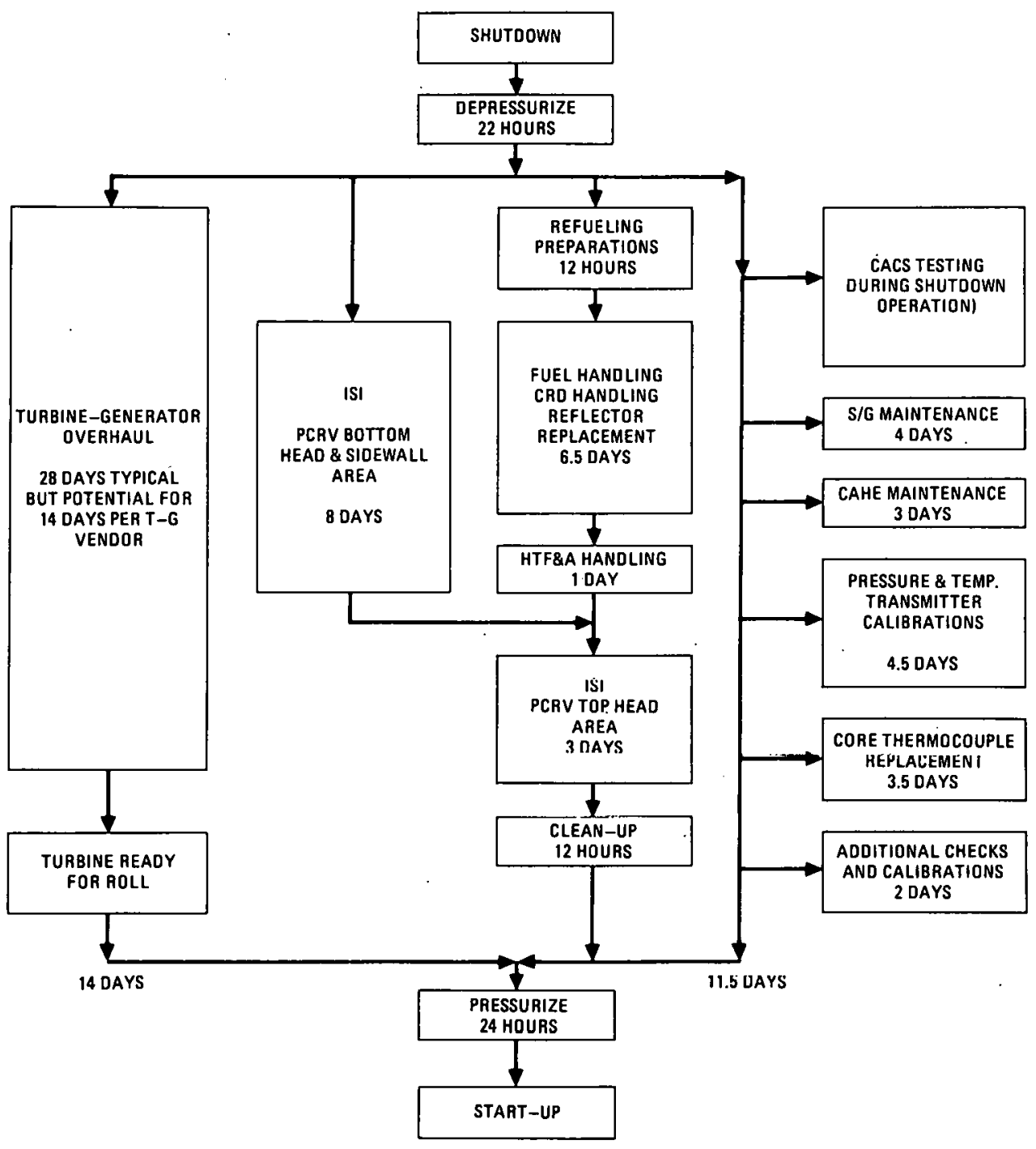

Fig. 7-1. HTGR-SC 9nก-MW(e) plant, typical annual refueling outage flow chart 
The maintenance and ISI required in addition to refueling for an HTGR may be divided into two basic parts: (1) maintenance and ISI which must be performed with the reactor shut down ( 9 days/yr tota1) and (2) maintenance and ISI that can be performed with the reactor operating at power, also $\sim 9$ days/yr total. The maintenance and ISI that must be done with the reactor shut down, may be further divided into two parts: (1) that which must be done with the reactor shut down and in sequence with refueling operations because of conflicts over space or equipment on the PCRV tophead ( 3 days/yr total) and (2) that which must be done with the reactor shut down but may be done concurrent with refueling ( 6 days/yr total). Only the 3 days/yr that must be done with the reactor shut down concurrent with refueling add to the duration of the refueling outage, because the remainder is masked by refueling operations or plant operations.

The 3, 6, and 9 days/yr time estimates above are considered to be the times required to do the required operations at $100 \%$ efficiency (i.e., no delays). When actually performed, they may be expected to take longer because of unavailability of manpower, tools, or materials; because of errors in planning by operators; or because of hardware failures. Reference 7-6 summarizes LWR plant refueling outage histories and indicates how much longer they may take. When the LWR data are fitted to a lognormal distribution, because of the apparent bias of the median toward the lower values, an uncertainty factor of two is obtained for the $90 \%$ confidence interval. This uncertainty factor of two is believed to be lower for the HTGR and the PBR because (1) metal-clad fuel will be eliminated, reducing the in-situ fuel leak testing, (2) fuel and hardware handling systems will be more automated and less subject to variations, and (3) significant improvement in operations planning and control are expected to be achieved before commercial HTRs are on-line. Therefore, this analysis uses an uncertalnty factor of 1.5 .

To indicate the possible range of scheduled outage times, the HTGR and PBR estimates of scheduled outages herein are assumed to represent the lower boundary of the $90 \%$ confidence interval. The $100 \%$ efficient estimate is, therefore, multiplied by 1.5 to obtain an estimate of the median value and 
the median value is multiplied by 1.5 to obtain an estimate of the upper boundary of the $90 \%$ confidence interval.

To systematically determine the differences that may exist between the two reactor types, four basic systems were identified as differing significantly due to the core concept. They are (1) the PCRV, (2) core and reactor internals, (3) core reactivity and flow control systems, and (4) refueling equipment. Maintenance service and inspection requirements were then assessed for activities pertinent to these systems for each reactor concept.

Figure 7-2 displays results with outage duration estimated for the lower, median, and upper boundaries of the $90 \%$ confidence interval described above. Two PBR cases are presented: schedule 2 is based on a KFA estimate for top and partial side reflector replacement, while schedule 3 represents an estimate by Hochtemperatur-Reaktorbau GmbH (HRB) for partial reflector replacement. The times shown are based on one replacement during the reactor lifetime with the total outage time distributed as an equivalent annual requi rement.

As Fig. 7-2 indicates, scheduled outage requirements for the on-line refueled pebble bed concept are of the same order as for the off-line refueled HTGR because of normal maintenance and ISI activities. For both concepts in steam-electric applications, turbine-generator maintenance appears to control outage duration. Schedule 4 represents a pocencial mini= mum time, while schedule 5 is more typical of current outages. The PBR outage time, however, may be slightly more flexible because the PBR on-line refueling can maintain excess core reactivity throughout the operating cycle. 
HTGR

\begin{tabular}{l} 
SCHEDULE \\
NO. \\
\cline { 2 - 5 } 1
\end{tabular}

2

\begin{tabular}{l} 
PBR \\
\begin{tabular}{|l|l|l|l|l|}
\hline SO & CONTROL ROD REPLACE & ISI & 砶 & SU \\
\hline
\end{tabular} \\
\hline
\end{tabular}

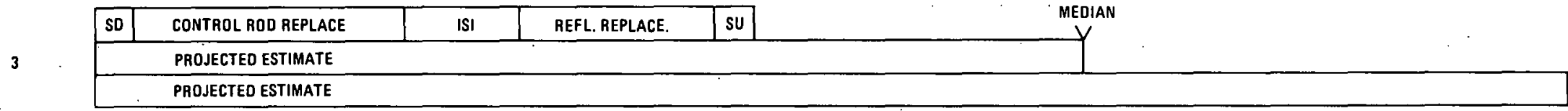

TURBINE-GENERATOR

\begin{tabular}{|l|l|l|}
\hline SD & TURBINE GENERATOR ESTIMATE & SU \\
\hline PROJECTED ESTIMATE & MEDIAN \\
\hline PROJECTEO ESTIMATE \\
\hline
\end{tabular}

5

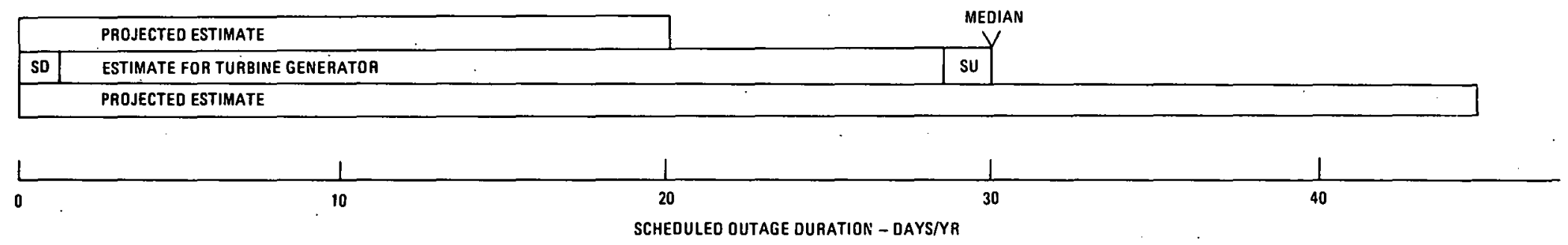

Fig. 7-2. Summary of scheduled outage requirement estimate for HTGR (prismatic core) and PBR (pebble core) 
REFERENCES

7-1. "HTGR-SC 900 MW(e) Reference Plant Nuclear Steam Supply System

Conceptual Design and Status Report," General Atomic Report GA-A15429, July 1979 .

7-2. "HTGR Accident Initiation and Progression Analysis Status Report. VII. Occupational Radiation Exposures from Gas-Borne and Plateout Activities," ERDA Report GA-A13617, General Atomic Company, January 1976 .

7-3. Engholm, B. A., "Personnel Radiation Exposure in HTGR and LWR Plants," General Atomic Report GA-A15569, September 1979.

7-4. Engholm, B. A., and S. Su, "Primary System Component Access-Shielding Study, Phase 1," General Atomic Report GA-D14948, June 1978.

7-5. "General Atomic Standard Safety Analysis Report (GASSAR)," Chapter 12, General Atomic Report GA-A13200, July 1975.

7-6. "Refueling Outage Trends in Light Water Reactors," Electric Power Research Institute Report EPRI NP-842, August 1978. 


\section{SAFETY ASPECTS OF A PBR AND PRISMATIC HTGR COMPARISON}

\subsection{ACCIDENT RISK COMPARISON}

Table 8-1 summarizes the review of design basis and Class 9 accidents important in the HTGR and PBR concepts. Relative safety performance could not be evaluated in a fully quantitative or probablistic manner due to insufficient available information and/or effort scope. Thus, the shift in the HTGR risk curve, established by the accident initiation and progression analysis (AIPA) Phase II (Ref. 8-1), could not be defined due to the pebble bed concept. However, Table 8-1 summarizes relative safety of the two concepts based on existing information and identifies additional detailed analyses required for quantifying the relative risk.

\subsubsection{Earthquakes}

The reactor core and PCRV internals are designed to industry code and regulatory standards which provide wide margins of safety for loadings imposed by earthquakes up to safe shutdown earthquake (SSE). Thus, structural failure of these components is not within design basis. However, for purposes of this safety comparison, the structural concerns, during earthquakes in excess of SSE (Class 9 events), for example, are listed. In the absence of a detailed seismic analysis comparison of pebble bed and prismatic cores, the fuel balls are expected to withstand the seismic forces better than the HTGR fuel blocks. Fuel element cracking could cause partial flow blockage and local overheating in the core. On the other hand, the PBR top cover reflector is supported and suspended from the top; its possible failure could cause reactivity insertion and overheating from flow blockage locally in the pebble bed if parts collapse on top of the bed. Also, control rod insertion may be impaired by top reflector collapse. Based on existing Information, Euch as the Mechanicc Rcocarch Inotitutc atudy (Refo. 8-1 through 8-4) failure of the HTGR core support structure is an extremely low 
TABLE 8-1

SAFETY CONPARISON OF PEDELE BED AID PRISMATIC COPE ACCIDENT ANALYSIS

\section{Safety Issue}

Earthquake effects on reactor internals - flow blockage and local overheating

Depressurization accidents

Spent fuel handling accidents

\section{Pebble Led/Prismatic Core Comparison}

Fuel element cracking a concern for prismatic core. Top reflector collapse a concern for PBR. Differences in core support structural behavior not quantifiable at this time.

Risk dominated by spurious lifting of PCRV relief valves or small pipe leaks for HTGR. For these, PBR risk should be similar. Nowever, PBR has additional possiblity of depressurization from fuel loading/removal system unquantifiable at this time. Consequences are 2 to 4 times lower for Pan.

Fuel element drop by fuel handling machine on unloading specific to HTGR.' Spillage of fuel balls on transfer to transport cart specific to

PBR. Drop or impact of fuel transfer cask or cart similar to both concepts.

Occurrence probabilities should be similar. HTGR release paths for fission products, in order of importance, are (1) dump lines, (2) steam relief valve, (3) PCRV relief valve per AIPA Phase II (Ref. 8-1) ; these should be similar for PBR Graphite oxidation should be higher for PBR by a factor of 2 because of corresponding higher surface area of balls compared to coolant channels in the block. Steam diffusion to fuel should be similar. Hydrolysis and attendant release of noble gases should be similar for $700^{\circ}$ and $850^{\circ} \mathrm{C}$ outlet temperature designs because failed fuel fraction is similar. PRR release probably is a factor of 1.5 lower for $950^{\circ} \mathrm{C}$ outlet temperature due to corresponding lower failed fuel fraction.
Required Pebble Bed Detailed Analysis

Translation of earthquake intensity into loading on PRE internals components. Probabilistic analysis of structural reliability including oxidation effects.

Reliability analysis of fuel loading/ removal systems for depressurization.

Reliability analysis of fuel unloading or removal; consequence analysis.

Application of HRB version of OXIDE-3 code for PBR oxidation, hydrolysis, pressures. 
TASLE 3-1 (Continued)

\section{Safety Issue}

Core heatup

\section{Probabilities}

Loss of off-site pover (LOSP) Should be same $\left(3 \times 10^{-6}\right)$ for both concepts leading to 1055 of forced

circulation (LDFC)

LOSP + - oss of main loop cooling (LlLC) leading to LOFC

Control rod insertion failure

Reserve shutdown system (RSS) insertion failure

Liner csoline. failure

Contalnment failure

\section{Consequences}

$\Lambda$ ferheat function

Heat cepacity

Axial heat transfer

Radial heat transfer

Initial temferatures

\section{Pebble Ped/Prismatic Core Comparison}

Should be same $\left(3 \times 10^{-5}\right)$ depending on core auxiliary cooling systen (CACS).

Should be similar $\left(10^{-3}\right)$. reflector collapse in PBR. failure $\left(10^{-1}\right)$ of fuel. similar.

Effective conductivities similar. PBR heat same. heat transfer.

\section{Required Pebble Red}

Detailed Analysis

Prismatic is $10^{-5}$. PCI should be notably higher.

Say be sinilar $\left(1 C^{-1}\right)$ depending on effect of top

Corresponds directly to liner cooling system

PER is $15 \%$ less due to lover core residence time

Similar for active core. Insufficient information for reflectors, tentatively assumed to be transfer area almost twice greater. due to larger diameter for large [3000-lW(t)] cores. For smaller plant ratings $1000-M W(t)$ area is the

Significantly higher for PER due to radiation

Negligible effect of differences in initial tenperature distribution. for PBP.

Analysis of thermal barrier failure after top reflector collapse.

CACS reliability analysis for PBR.

Control rod drive (CRD) reliability

Reflector heat capacity analysis. 
TABLE 8-1 (Continued)

\section{Safety Issue}

Fission product release

Containment failure time

Boron-carbide slumping (reactivity poịsons)

$\mathrm{B}_{4} \mathrm{C}$ vapor diffusion in graphite

Maintenance of shutdown margin

\section{Pebble Bed/Prismatic Core Comparison}

Should be somewhat slower in PBR due to slower heatup of core.

Should be longer for $\mathrm{PBR}$ in sequences with liner cooling failure due to lower afterheat (higher heat transfer works opposite).

Dead-end channels limit slumping in HTGR to four blocks voided for CRD and three blocks voided for RSS. PBR case may be worse due to no constraints.

Should occur later in PBR due to lower temperatures: diffusion enhanced by higher power factors at top of core and greater surface area of balls in PBR.

Tradeoff between PBRs lower temperatures and enhanced $\mathrm{B}_{4} \mathrm{C}$ diffusion and HTRGs limited slumping.
Required Pebble Bed Detailed Analysis

PBR concrete degradation analysis.

Need experimental data.

Need experimental data.

SORS code analysis of $\mathrm{B}_{4} \mathrm{C}$ behavior and corresponding reactivity analysis. 
probability event, even considering graphite oxidation effects over the life of the plant. Although the PBR core support design is different, its structural reliability may also be high enough that any differences with HTGRs may be unimportant. However, reliability analysis of the PBR core support design is needed for verification. An area of particular concern is displacement of the core internals relative to the PCRV bottom head requiring deflection of the pebble fuel discharge channel structures axially spanning the core exit plenum region.

In summary, the concept comparison for earthquake safety seems to be governed by relative structural reliability of HTGR fuel blocks and the PBR top cover reflector and fuel discharge channels. Relative reliabilities of the core support structure are not expected to be important, since extremely low failure probability must be achieved for both concepts.

\subsubsection{Depressurizations}

In terms of publi.ic. health effects, AIPA Phase I, Volume VI (Ref. 8-5) showed that the major dose is the external whole body gamma dose due to release of noble gases in the circulating primary coolant activity. This is. opposed to licensing analysis where Sr-90 and I-131 contributions to inhalation doses are more important. Core performance analysis indicates that circulating noble gases are two to four times lower for PBR. Thus, consequences of depressurlizalion may be concluded to be twn to four times lower for PBR.

Regarding probability and risk of depressurization, events of highest risk in AIPA were (1) spurious lifting of PCRV relief valves and (2) rupture of small instrument or pipe lines penetrating the primary coolant boundary. Large penetration failure was of lower risk due to low probabilicy. The PBR should be stmilar in these rcgarde. However, the PBR fuel loading and removal systems (at PCRV pressure or higher) present unique possibilities for additional paths of depressurizations. Lacking a comprehensive reliability analysis for these systems, whether depressurizations in these systems can constitutc a significant risk contribution is not known. However, the 
preliminary availability analysis (Ref. 8-6) indicates a relatively low probability of failure. Therefore, the preliminary indications are that the probabilistic risk of depressurization accidents is likely somewhat lower for PBR due to lower consequences.

\subsubsection{Spent Fuel Handling Accidents}

This class of accidents does not contribute significantly to the overall risk envelope. However, there are safety implications in the HTGR concept for (1) postulated drop of a spent fuel element block on unloading of the core or (2) drop of a shipping container loaded with six fuel blocks as analyzed in AIPA Phase I, Volume III (Ref. 8-7) : Equivalent PBR events can occur on transfer of spent element balls to the fuel transport cart. Without a reliability analysis of the fuel removal system, the PBR risk has not yet been shown to be much different than that for HTGRs.

\subsubsection{Water Ingress}

Occurrence probabilities for water ingress (analyzed in detail in Ref. 8-1, Section 5, for steam generators) should be independent of core design, since they are dominated by random defects or failures in the secondary coolant boundary. For a steam cycle plant, the major risk release pathways are through the secondary system and to the atmosphere via failed open steam relief valves or failed open dump valves (SG-1 and SG-2 release categories in Ref. 8-1, respectively). Again, this should be similar for the PBR. Regarding consequences, the following conclusions are made:

1. Graphite oxidation in PBR would be about a factor of two higher, because the surface area of the fuel pebbles is about twice the surface area of the coolant channel surface area in prismatic blocks (most oxidation occurs near the surface when temperatures are still high). Higher mass transfer coefficient at the surface 
should not affect oxidation significantly, since the reaction is controlled by the in-pore diffusion rate rather than boundary layer transport.

2. Steam would diffuse to the fuel when temperatures begin to cool, and all $\mathrm{UC}_{2}$ particles with failed coatings would hydrolyze with attendant release of noble gases. $U_{2}$ failed fuel fractions for the $\mathrm{PBR}$ are similar to HTGR fractions for core outlet temperatures of $700^{\circ} \mathrm{C}$ and $850^{\circ} \mathrm{C}$ and are expected to be somewhat higher for $950^{\circ} \mathrm{C}$ (Table 4-3). Thus, no significant difference should occur in fission gas release for these cases. For the $950^{\circ} \mathrm{C}$ core outlet temperature $\mathrm{PBR}$, with $\mathrm{UC}_{2}$ failed fuel fractions about a factor 1.5 higher for prismatic fuel, the fission gas release due to hydrolysis would be 1.5 times lower for the PBR.

In summary, the risk of water ingress is similar to PBR and HTGR designs with outlet core temperatures to $850^{\circ} \mathrm{C}$. At $950^{\circ} \mathrm{C}$ outlet temperature, the PBR risk is somewhat smaller.

\subsubsection{Core Heatup}

As indicated in Table 8-1, initiating event probabilities leading to core heatup are expected to be similar for PBR as previously analyzed in AIPA Phase II (Ref. 8-1) for HTGRs. This is because the key faults initiate either in the cooling systems [main loop and core auxiliary cooling system (CACS)], assumed to be similar for both concepts, or in electrical supply systems. However, subsequent events may be different, especially if governed by core response. One such event is insertion of the control rods (SCRAM). Since the HTGR control rod drive (CRD) is largely passive (gravity insertion) and the PBR control rods require force insertion, the HTGR reliability (10-5 per Ref. 8-1) seems inherently better. However, in sequences in which control rods failed to shut down, the reactor did not contribute to the overall core heatup risk in the AIPA study. A licensed PBR control rod system could probably not have low enough reliability for failure to scram sequences to 
become important for the PBR risk curve. Detailed reliability analyses are required for verification.

Since the PBR reserve shutdown system is similar in concept to that of the HTGR, it is judged to have a similar reliability $\left(10^{-3}\right.$ per demand). Lacking analyses of convective, radiative, and conductive heat transfer from the core to the thermal barrier, liner, and liner cooling system for the PBR design, the change in overall probability of liner cooling system failure $\left(10^{-1}\right)$ and resulting concrete degradation and later containment failure cannot be assessed. One difference expected is the melting of metal supports for the top cover reflector and collapse of the top reflectior on the pebble bed core. Based on existing information, whether this would greatly affect liner cooling system failure is not clear. However, it could have a positive reactivity effect.

Overall, probabilities of core heatup initiation and important subsequent events are judged to be similar for both concepts.

Regarding consequences, the PBR has an afterheat function which is $\sim 15 \%$ lower (Ref. 8-4) than that for the HTGR. Along with core heat capacity and thermal conduction out of the core, the afterheat governs the temperature rise. Initial temperatures or temperature distributions exert little influence on the heatup transient and resulting fission product release, because the initial heat difference is small compared to the decay heat generation in the initial few hours. In fact, the heat content difference is equivalent to only $\sim 0.5 \mathrm{~h}$ of initial heat generation. Shifting the heatup temperature curves by $0.5 \mathrm{~h}$ has negligible effect. The lower power density of the PBR active core was found to just offset the higher void fraction (39\% versus $20 \%$ ). Graphite heat capacities of the active core should then be the same. However, the active core graphite only constitutes about one-third of the total prismatic core graphite. The rest is due to the reflectors. Insufficient information was available on the pebble bed reflector mass. The PBR active core is larger in size. However, the drawings indicate that 
PBR/prismatic reflector masses are equivalent. As far as can be determined, total core heat capacities are about the same for the two concepts.

The third aspect of the heatup transient is the heat transport from the core. The larger PBR active core size causes the circumferential heat transfer area to be slightly greater and the axial heat transfer area to be almost a factor of two greater. The prismatic core has a higher axial effective conductivity due mainly to radiation up the coolant channels. Reference 8-9 discusses the basis for the pebble bed effective conductivity. Apparently, for the high temperature levels of interest in heat-up evaluation, the effective conductivity of the pebble bed in all directions is equivalent to that for the prismatic core in the axial direction. Therefore, the pebble bed core will transfer twice as much heat axially (due to frontal area) as the prismatic core and several times more heat radially (mainly due to radiation in the radial direction in the packed bed). This, coupled with $15 \%$ lower afterheat, should result in lower temperatures in the pebble bed core. Fission product release would also be slower.

A final consideration for core heatup is reactivity effects. Analysis for the prismatic core indicates that slumping of the boron carbide compacts of the control rods is limited to about four blocks voided at the top of the active core after $\sim 100 \mathrm{~h}$. Reserve shutdown boron carbide balls do not slump beyond about. three fuel blocks voided at the top. This slumping is initiated near the center of the core where the axial power distribution peaks and where temperatures are maximum. The less hot compacts or balls at top compress on the softer $\mathrm{B}_{4} \mathrm{C}$ at the center, voiding the upper part of the control channels. However, SORS computer code calculations indicate that boron vapor diffuses into the graphite at top. This effectively maintains shutdown margins, because the boron is finely dispersed and not as self-shielded as in the balls or compacts. Physics calculations indicate that reactor shutdown margins are maintained even for four blocks voided in the CRD channels and three blocks voided for the reserve shutdown system (RSS) channels. The dead-ending of the channels at the bottom prevents further slumping. 
The PBR has no constraints to prevent slumping of the boron carbide KLAK downward in the packed bed. However, the lower temperatures of the pebble bed core may reduce slumping. To the extent slumping occurs, it would be greatest near the top of the core where axial power factors are maximum but where boron diffusion into the graphite is also greatest. Higher surface area of the balls enhances diffusion. These arguments indicate that a reactivity problem may not be created by the PBR design lacking a structural limitation of $\mathrm{B}_{4} \mathrm{C}$ slumping. Detalled analysis of the kind performed by the SORS code and applicable physics codes need to be performed for quantification.

\subsection{CIRCULATING ACTIVITY}

The radiological safety effects relative to the magnitude of primary coolant circulating activity during normal plant operation were reviewed. off-site doses to the public and occupational exposure to workers during containment access were considered.

The major radionuclide class contributing to airborne pathway exposure offsite and during containment access is the circulating inventories of noble gases. From evaluation of major nuclide contributors to both offsite and occupational exposed personnel, $\mathrm{Kr}-88$ clearly dominates offsite exposure for all containment purge rates. For containment access considerations, $\mathrm{Kr}-88$ again dominates for purged containment configurations but contributes equally with long half-life Xe-133 for closed containment with infrequent purges.

For a closed containment, if containment access were not a consideration, the upper-bound circulating Level A activity of noble gases, assuming $3: 65 \% / y r$ PCRV leakage of primary coolant; would be $10^{7} \mathrm{Ci}$, most importantly. $2 \times 10^{6} \mathrm{Ci}$ of $\mathrm{Kr}-88$, before maximum offsite dose limits are reached. Corresponding upper bound circulating I-131 inventory would be $2200 \mathrm{Cl}$. However, to enable $40 \mathrm{~h} / \mathrm{wk}$ containment access, the $\mathrm{Kr}-88$ inventory would be limited to $3900 \mathrm{Ci}$ ( I-131 limited to $1.4 \mathrm{Ci}$ ). 
For an open containment of the size expected for about a 2200-MW(t) unit, with $0.5 \mathrm{vol} / \mathrm{h}$ purge rate and $3.65 \% / \mathrm{yr}$ of unbuffered PCRV leakage of primary coolant, $14,000 \mathrm{Ci}$ of $\mathrm{Kr}-88$ (74,000 $\mathrm{Ci}$ of all noble gases) would be the upper bound simultaneously for offsite doses and occupational doses at $40 \mathrm{~h} / \mathrm{wk}$ containment access. About $6.8 \mathrm{Ci}$ of $\mathrm{I}-131$ would be the upper bound for the thyroid exposure limits.

Table 8-2 presents the results of the core performance assessment and corresponding containment access times and offsite doses due to expected circulating gaseous activity levels. As shown, annual offsite doses are somewhat lower for the pebble-bed concept compared to the similar prismatic core design. Also, containment access times are improved for the pebble bed. With these Level A expected inventories, the use of which is normally allowed in past licensing for offsite exposure, the 10CFR50 Appendix I (Ref. 8-10) limits are met for both the prismatic and pebble bed core designs. However, to satisfy Appendix I ALARA requirements, a margin of a factor of four between expected (Level A) activity and the design limit (Level B) is provided. With license basis PCRV leakage and assuming 100\% hydrolysis of defected fuel particles, some further optimization of the prismatic designs for $850^{\circ}$ and $950^{\circ} \mathrm{C}$ is appropriate to keep Level B activity below Appendix I limits. All of the pebble bed cases analyzed meet the Appendix I limits with design level inventory. 
TABLE 8-2

COMPARISON OF OFFSITE DOSES AND CONTAINMENT ACCESS

DURING NORMAL OPERATION FOR PEBBLE BED (PBR)

AND PRISMATIC CORE (HTGR)

\begin{tabular}{|c|c|c|c|c|c|}
\hline \multirow[b]{2}{*}{ Plant } & \multirow{2}{*}{$\begin{array}{c}\text { Core } \\
\text { Outlet } \\
\text { Temp } \\
\left({ }^{\circ} \mathrm{C}\right) \\
\end{array}$} & \multirow{2}{*}{$\begin{array}{c}\text { Expected } \\
\text { Kr-88 } \\
\text { Circulating } \\
\text { Activity (a) } \\
\text { (Ci) }\end{array}$} & \multirow{2}{*}{$\begin{array}{c}\text { Offsite } \\
\text { Dose } \\
\text { EAB } \\
\text { (mrem/yr) }\end{array}$} & \multicolumn{2}{|c|}{$\begin{array}{c}\text { Containment Access } \\
\text { Time (h/wk) }\end{array}$} \\
\hline & & & & Open & Closed \\
\hline $\begin{array}{l}3000 \mathrm{MW}(\mathrm{t}) \\
\text { HTGR-GT }\end{array}$ & 850 & 4000 & 1.4 & $>40$ & $>35$ \\
\hline $\begin{array}{l}3000 \mathrm{MW}(\mathrm{t}) \\
\text { PBR-GT(b) }\end{array}$ & 850 & 2190 & 0.8 & $>40$ & $>40$ \\
\hline $\begin{array}{l}1170 \mathrm{MW}(\mathrm{t}) \\
\text { HTGR-SC }\end{array}$ & 700 & 1430 & 0.5 & $>40$ & $>40$ \\
\hline $\begin{array}{l}1170 \mathrm{MW}(t) \\
\text { PBR-SC }(c)\end{array}$ & 700 & 450 & 0.2 & $>40$ & $>40$ \\
\hline $\begin{array}{l}1170 \mathrm{MW}(\mathrm{t}) \\
\text { HTGR-PH }\end{array}$ & 950 & $1885(e)$ & 0.7 & $>40$ & $>40$ \\
\hline $\begin{array}{l}1170 \mathrm{MW}(\mathrm{t}) \\
\operatorname{PBR}-\mathrm{PH}(\mathrm{f})\end{array}$ & 950 & 1340 & 0.5 & $>40$ & $>40$ \\
\hline
\end{tabular}

(b) Assuming $100 \%$ hydrolysis of falled $\mathrm{UC}_{2}$. Pebble bed reactor gas turbine.

(c) Pebble bed reactor steam cycle.

(d) High-temperature gas-cooled reactor-process heat.

(e) Reflects anticipated improvements in fuel particle performance model (Table 4-3).

(f) Pebble bed reactor-process heat. 


\section{REFERENCES}

8-1. "HTGR Accident Initiation and Progression Analysis Status Report, Phase II Risk Assessment," DOE Report GA-A15000, General Atomic Company, Apri1 1978 .

8-2. Mackenzie, D. W., "HTGR Core Support Structure Reliability Study," Mechanics Research, Inc. Report MRI-2801-02, July 1975.

8-3. Mackenzie, D. W., and D. L. Platus, "Further HTGR Core Support Structure Reliability Studies, Interim Report No. 2," Mechanics Research, Inc. Report MRI-2864-02, March 1976.

8-4. Platus, D. L., "Further HTGR Core Support Structure Reliability Studies, Interim Report No. 1," Mechanics Research, Inc. Report MRI-2865-01, January 1976.

8-5. "HTGR Accident Initiation and Progression Analysis. VI. Event Consequences and Uncertainties Demonstrating Safety R\&D Importance of Fission Product Transport Mechanisms," ERDA Report GA-A13617, Vol. VI, January 1976 .

8-6. "Pebble Bed Reactor Review Update, Fiscal Year 1979 Anual Report," DOE Report GA-A15687, General Atomic Company, January 1980.

8-7. "HTGR Accident Initiation and Progression Analysis. III. Preliminary Results (Including Design Options)," ERDA Report GA-A13617, Vol. III, November 1975 .

8-8. "U.S./FRG Joint Pebble Bed Reactor Evaluation, Final Report for Fiscal Year 1977," DOF Report GA-A14611, Genera1 Atomic Company, October 1977 .

8-9. Breitbach, G., "Warmetransportvorgange in Kugelschuttungen unter besonderer Berueksichtigung der Strahlung," KFA/IRB Report Ju1-1564, ISSN 0366-0885, December 1978.

8-10. "Numerical Guide for Design Objectives and Limiting Condition for Operation to Meet the Criterion 'As Low as Practicable' for Radioactive Material in. Light Water Copled Nuclear Power Reactor Effluents, "in Code of Federal Regulations, Tit1e 10, Part 50, Appendix I, U.S. Government Printing office, Washingtion, D.C., 1977. 


\section{PCRV DIMENSIONS}

In support of an assessment of nuclear island cost difference between the prismatic fuel HTGR and PBR, a directly comparable PBR PCRV configuration was developed based on the HTGR-GT PCRV used in the ERDA-109 assessment (Ref. 9-1). With the plant rating held constant for the comparison, all heat exchanger cavities remained the same for the two PCRVs with only the core cavity dimensions changed to accommodate the PBR core geometry. The larger core cavity in turn required increased side wall ligament thicknesses and greater head thickness for the same operating pressure conditions. Table 9-1 summarizes the dimensions and quantities generated for the comparable PCRVs. These values were used by ORNL for plant cost comparisons. The resulting PBR PCRV is considerably more costly than the counterpart prismatic HTGR vessel due to the differences in core dimensions. Although core design adjustments are possible for the PBR, this comparison reflects selected reference core designs for the two concepts.

\section{REFERENCE}

9-1. "Technical and Economic Assessment of the Direct Cycle Gas Cooled Keactor Plant," ERDA Report ERDA-IUY, United Engineers and.Constructors and Holifield National Laboratory, NASA Lewis Research Center. 
TABLE 9-1

PCRV DATA

\begin{tabular}{|c|c|c|}
\hline Item & $\begin{array}{l}\text { Prismatic } \\
\text { HTGR }\end{array}$ & Pebble Bed \\
\hline Max cavity pressure (MCP) (bar) & 77 & 77 \\
\hline PCRV diameter (m) & 39.2 & 46.3 \\
\hline PCRV height (m) & 35.1 & 39.7 \\
\hline Heat exchanger cavity diameter (m) & 5.0 & 5.0 \\
\hline Turbomachine cavity diameter (m) & 4.1 & 4.1 \\
\hline Core cavity diameter (m) & 11.3 & 11.3 \\
\hline Core cavity height (m) & 14.4 & 15.5 \\
\hline PCRV top head thickness (m) & 7.9 & 10.4 \\
\hline PCRV concrete volume $\left(\mathrm{m}^{3}\right)$ & 35,550 & 57,980 \\
\hline Reinforcement steel ( $\left.\mathrm{kg} \times 10^{6}\right)$ & 1.36 & 2.29 \\
\hline Number of vertical tendons & 732 & 922 \\
\hline Number of horizontal tendons & 336 & 336 \\
\hline $\begin{array}{l}\text { Circumferential wire length } \\
\left(\mathrm{m} \times 10^{6}\right)\end{array}$ & 3.39 & 4.70 \\
\hline $\begin{array}{l}\text { Circumferential wire weight } \\
\left(\mathrm{kg} \times 10^{6}\right)\end{array}$ & 3.39 & 4.71 \\
\hline Linear total area $\left(\mathrm{m}^{2} \times 10^{3}\right)$ & 7.0 & 7.47 \\
\hline $\begin{array}{l}\text { Liner and penetration weight } \\
\left(\mathrm{kg} \times 10^{6}\right)\end{array}$ & $2.99(a)$ & 3.27 \\
\hline Cooling tube length $(\mathrm{b}),\left(\mathrm{m} \times 10^{3}\right)$ & 48.5 & 53.2 \\
\hline Insulation $\left(\mathrm{m}^{2} \times 10^{3}\right)$ & 7.0 & 7.47 \\
\hline
\end{tabular}

(a)

(b) ERDA-109 weight (Ref. 9-1)

Based on actual liner and penetration surface area. 


\section{FUEL REPROCESSING COST ESTIMATE}

GA studied PBR fuel reprocessing and prismatic element HTGR spent fuel transportation information and cost estimates. This study was part of the HTR core evaluation study coordinated by ORNL.

Specifically, GA defined processes and equipment requirements and provided conceptual cost estimates for reprocessing spent PBR fuel, based on a specified reference HTR fuel cycle. Comparative cost estimates were for a specified prismatic element reactor fuel based on a comparable reference HTGR fuel cycle. The cost estimates were for reprocessing plants sized to service a reactor economy of $\sim 20-G W(e)$ installed capacity. Cost estimate ground rules were based on prior assessment studies performed for the Alternative Fuel Cycle Evaluation Program (AFCEP).

A common set of ground rulcs for the reproccssing and spent fuel shipping cost studies was followed to provide cost estimates that are generally comparable and sultable for overall reactor economic assessments. The reference processes, equipment, and facility requirements were defined in an internally consistent manner. Common economic assumptions for this comparative cost study included considering common licensing regulations for constructing and operating the reprocessing plants and for internally consistent equipment, material, and labor coste.

Either the HTGR or the PBR concept can be operated on a variety of fuel cycles and with a variety of fuel designs at the discretion of the reactor designer. This flexibility in fuel cycle variables, such as enrichment, carbon-to-heavy metal ratios, fuel element residence time in-core, power density, and fuel burnup, makes directly comparable cases difficult to obtain without specifically optimizing each system for a given element design and fuel cycle definition. Consequently, in performing this cost study, selected 
specific reactor fuel cycles and fuel designs previously defined by the ORNL participants had to be used.

The specific pebble bed and prismatic reactor fuel cycles were selected by ORNL to provide generally comparable reactor characteristics in terms of conversion ratios and carbon-to-heavy metal ratios and are based on a highly enriched uranium-thorium recycle fuel cycle. Table 10-1 summarizes the selected cases. The load factor used is not representative of any inherent difference but, rather, happened to be the values used in the source information. GA has concluded that the PBR does not offer an availability advantage. Also, the much lower burnup selected for the PBR case distorts any direct comparison of reprocessing economics based on cost per unit of heavy metal throughput of the reprocessing plant. The apparent small plant efficiency difference reflects the more conceptual nature of the PBR studies used for this case.

The quantities of major materials, items, or elements to be processed annually through the two respective reprocessing plants were derived from published equilibrium heavy metal discharge information for the two fuel cycles. Capacity of the prismatic fuel element reprocessing plant was set at 20,000 spent fuel elements per year. Accordingly, this reprocessing plant is capable of servicing an economy of somewhat less than $20 \mathrm{GW}(e)$ for HTGR reactors on a 4-yr fuel cycle. Capacity of the pebble fuel element reprocessing plant was set at 20,000,000 spent fuel elements per year. This plant would also service an economy of somewhat less than $20 \mathrm{GW}(e)$ when the PBR reactors operate on a 3-yr fuel cycle. Table 10-2 summarizes and compares the annual reprocessing plant throughputs.

The major differences in reprocessing plant annual throughput requirements for the pebble bed and prismatic HTR concepts arise primarily from the following factors:

1. The PBR operates on a 3-yr fuel lifetime cycle. The prismatic reactor operates on a 4-yr cycle. 
TABLE 10-1

PRELIMINARY COMPARISON OF PRISM/PEBBLE BED REACTOR CYCLE CHARACTERISTICS

\begin{tabular}{l|l|c}
\hline \multirow{2}{*}{\multicolumn{1}{c|}{ Cycle Titles }} & \multicolumn{2}{c}{ Recycle Cases } \\
\cline { 2 - 3 } & $\begin{array}{c}\text { Pebble } \\
\text { Bed } \\
\text { Th/U }\end{array}$ & $\begin{array}{c}\text { Prismatic } \\
\text { HEU(5)/HEU(3)-Th } \\
\text { Recycle }\end{array}$ \\
\hline Design thermal power [MW(t)] & 3000 & 3360 \\
Design electric power [MW(e)] & 1200 & 1332 \\
$\begin{array}{l}\text { Plant efficiency } \\
\text { electric/thermal power }\end{array}$ & 0.4 & 0.396 \\
$\begin{array}{l}\text { Load factor } \\
\text { Annual electricity } \\
\text { generation [MW(e)/yr] }\end{array}$ & 0.8 & 0.75 \\
$\begin{array}{l}\text { Fuel elements per core } \\
\text { Fuel elements replaced } \\
\text { per yr }\end{array}$ & 960 & 999 \\
Core power density (W/ $\mathrm{cm}^{3}$ ) & $3,233,370$ & 5288 \\
$\begin{array}{l}\text { Average burnup (MWd/kg } \\
\text { lieavy metal) }\end{array}$ & $1,111,720$ & 1322 \\
$\begin{array}{l}\text { Conversion ratio (av } \\
\text { during equilibrium) }\end{array}$ & 5.0 & 7.1 \\
$\begin{array}{l}\text { Number of atoms carbon/ } \\
\text { heavy metal }\end{array}$ & 36.5 & 59.5 \\
\hline
\end{tabular}


TABLE 10-2

REPROCESSING PLANT DESIGN BASIS (ANNUAL THROUGHPUT)

\begin{tabular}{l|l|l}
\hline \multirow{2}{*}{ Items to be Processed } & \multicolumn{2}{|c}{ Fuel Element Type } \\
\cline { 2 - 3 } & \multicolumn{1}{|c}{ Pebble Bed } & Prismatic \\
\hline Fuel elements & $20 \times 10^{6}$ & $20 \times 10^{3}$ \\
Carbon (kg) & $3.67 \times 10^{6}$ & $1.88 \times 10^{6}$ \\
Heavy metals (total) (kg) & $343.4 \times 10^{3}$ & $229.6 \times 10^{3}$ \\
Uranium (kg) & 17,420 & $12,012$. \\
Thorium (kg) & $326.0 \times 10^{3}$ & $217.4 \times 10^{3}$ \\
Plutonium (kg) & 45 & 120 \\
Fission products (total) (kg) & $16.9 \times 10^{3}$ & $19.2 \times 10^{3}$ \\
\hline
\end{tabular}


2. The carbon-to-heavy metal ratio is higher for the reference pebble bed fuel cycle than for the reference prismatic fuel cycle.

3. The average burnup for pebble bed fuel is considerably lower than that for prismatic fuel in the comparison cycles.

4. The reference PBR core operates at a lower power density than does the reference prismatic reactor core.

The GA cost study provides the reprocessing plant unit cost bases (capital and operating cost estimates) and throughput rate assumptions required by ORNL to apply to further comparative economic analyses of the PBR and HTGR concepts.

Table 10-3 summarizes the basic reprocessing capital and operating costs and throughput rates for use in economic analyses. The capital cost totals in Table 10-3 are considered to be the most likely values, with a probable uncertainty range of $+10 \%,-20 \%$. The operating cost totals in Table $10-3$ are also considered to be most likely values, with a probable uncertainty range of $+15 \%,-5 \%$ on operating costs.

At the request of ORNL, GA also estimated.incremental capital and operating costs for reprocessing of a TRISO pebble-bed fuel design option. The results indicated a reproceesing cost increase of $\sim 5 \%$ for TKisu-coated fuel. 
TABLE 10-3

REPROCESSING PLANT UNIT COST BASIS

HEU FUEL RECYCLE

\begin{tabular}{l|l|l}
\hline & Prismatic & Pebble Bed \\
\hline Fue1 elements/yr & 20,000 & $20,000,000$ \\
Reactor economy, net [GW(e)] & $\sim 20$ & $\sim 20$ \\
Capital cost (1978 \$ millions) & & \\
Facility & 171.5 & 210.6 \\
Equipment & $\underline{364.5}$ & 395.8 \\
Total(a,b) & 536.0 & 606.4 \\
Operating cost (1978 \$millions) & & \\
Hardware & 21 & 24 \\
Other & $\underline{19}$ & $\frac{21}{40}$ \\
Total(c) & 40 \\
\hline
\end{tabular}

(a) Excluding replacement cost.

(b) The plants include $40 \%$ contingency on capital cost.

(c) The plants include $20 \%$ contingency on operating cost. 


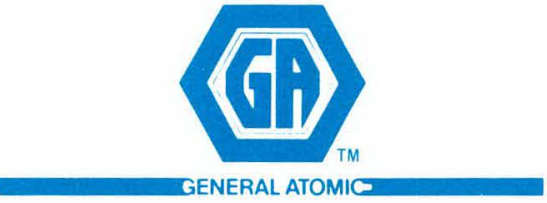

GENERAL ATOMIC COMPANY

P. O. BOX 81608

SAN DIEGO, CALIFORNIA 92138 